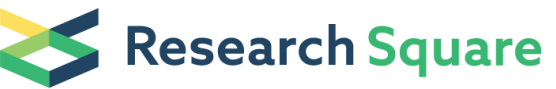

\section{Warming enhanced the climate temporal effects on vegetation across Siberia}

\section{Shangyu Shi}

Institute of Geographic Sciences and Natural Resources Research CAS: Institute of Geographic Sciences and Natural Resources Research Chinese Academy of Sciences https://orcid.org/0000-0001-5606-5127 Ping Wang ( $\nabla$ wangping@igsnrr.ac.cn )

Institute of Geographic Sciences and Natural Resources Research CAS: Institute of Geographic Sciences and Natural Resources Research Chinese Academy of Sciences https://orcid.org/0000-0003-2481-9953

\section{Yichi Zhang}

Institute of Geographic Sciences and Natural Resources Research CAS: Institute of Geographic Sciences and Natural Resources Research Chinese Academy of Sciences

\section{Jingjie Yu}

Institute of Geographic Sciences and Natural Resources Research CAS: Institute of Geographic Sciences and Natural Resources Research Chinese Academy of Sciences

\section{Research}

Keywords: climate factors, vegetation index, temporal effects, cumulative effects, time-lag effects, Siberia

Posted Date: April 5th, 2021

DOI: https://doi.org/10.21203/rs.3.rs-365406/v1

License: (c) (1) This work is licensed under a Creative Commons Attribution 4.0 International License. Read Full License 


\section{Warming enhanced the climate temporal effects on vegetation across}

\section{Siberia}

Shangyu Shi ${ }^{\text {a,b }}$, Ping Wang ${ }^{\mathrm{a}, \mathrm{b}, *}$, Yichi Zhang ${ }^{\mathrm{a}}$, Jingjie Yu ${ }^{\mathrm{a}, \mathrm{b},{ }^{*}}$

a: Key Laboratory of Water Cycle and Related Land Surface Processes, Institute of Geographic Sciences and Natural Resources Research, Chinese Academy of

Sciences, Beijing 100101, China;

b: University of Chinese Academy of Sciences, Beijing 100049, PR China;

\section{Abstract:}

Widespread climate warming and growing season greening have been observed across most of the Northern Hemisphere in recent decades. However, the response of greening to amplified warming remains unclear with regard to the temporal effects (cumulative and time-lag effects) in cold regions of the Northern Hemisphere. We therefore provide a comprehensive analysis of the relationship between the enhanced vegetation index (EVI) and climate factors (e.g., land surface temperature (LST), precipitation, and solar radiation) across Siberia, which is experiencing rapid warming and greening, during 2000-2016 by using a random forest regression model. We found that solar radiation was the dominant driving factor of vegetation greening in $55.95 \%$ of the study area (concentrated in southwest Siberia), followed by temperature $(41.28 \%$, concentrated in northeast Siberia) and precipitation (2.78\%). Furthermore, the cumulative and time-lag effects increased the explanation of vegetation variation by climate factors, from 0.71 to 0.78 , and were observed in more than $80 \%$ of the area of Siberia. The average cumulative duration was $3.61 \pm 1.97$ months, and the time-lag period was $1.51 \pm 1.20$ months, with the longest term found in deciduous broadleaf forests and the shortest

\footnotetext{
* Corresponding author at: Key Laboratory of Water Cycle and Related Land Surface Processes, Institute of Geographic Sciences and Natural Resources Research, Chinese Academy of Sciences, Beijing 100101, China; E-mail address: wangping@igsnrr.ac.cn (Ping Wang); yujj@igsnrr.ac.cn (Jingjie Yu)
} 
term found in shrublands. Our results indicated that the vegetation activities were influenced by cumulative effects combined with time-lag effects. The temporal effects varied with land cover categories, and the complex ecosystem generally corresponded to long-term temporal effects, and vice versa. Hence, the tundra shrub converted to boreal forest caused by warming in Siberia enhanced the climate temporal effects.

Keywords: climate factors; vegetation index; temporal effects; cumulative effects; time-lag effects; Siberia

\section{Introduction:}

The global climate system has been experiencing a dramatic change characterized by warming over the past century (Qin 2004; Pecl et al. 2017), and climate change has profound effects on the functioning of terrestrial ecosystems. Vegetation is a crucial component of terrestrial ecosystems, as it combines the energy, water and carbon exchanges between the land surface and atmosphere (Law et al. 2002). The identification of the persistence and resilience of terrestrial ecosystems under climate change has been a global research priority (McMahon et al. 2011; Garcia et al. 2014; Piao et al. 2019).

The response of vegetation to climate change has been a general indicator used to evaluate terrestrial ecosystem conditions (Deng et al. 2019). The impact of climate change on vegetation has been well documented by previous studies through direct or indirect perspectives (Nemani et al. 2003; Buitenwerf, Rose \& Higgins 2015). Vegetation activities are directly affected by external climate forcing (Seddon et al. 
2016). For instance, temperature is closely related to vegetation photosynthesis and respiration ( $\mathrm{Hu}$ et al. 2016). It has been shown that increasing temperature improves vegetation productivity and prolongs the growing season in high-latitude and highaltitude areas (Myers-Smith et al. 2020). Precipitation (PRE) is an indispensable source of moisture for terrestrial ecosystems and is associated with the processes of various vegetation activities, especially in arid and semiarid areas where PRE is the primary factor restricting vegetation growth (Vicente-Serrano et al. 2013). Solar radiation (SR) reflects the potential heat available for vegetation activities and significantly influences metabolic processes. Additionally, SR is related to environmental light intensity, which is considered a major factor regulating vegetation growth (Feng et al. 2016). Furthermore, other factors triggered by climate change influence vegetation activities, as the complexity of vegetation biophysics and biochemistry processes. For example, the frequency and/or intensity of extreme events such as drought (Vicente-Serrano et al. 2013), floods (Abril et al. 2014), wildfires (Mack et al. 2011) and extreme temperatures (Baumbach et al. 2017) have increased significantly on a global scale, which has greatly impacted the global ecosystem (Walsh et al. 2020).

In addition to studies focused on the vegetation response to climate change based on simultaneous climate factors, an increasing number of studies have demonstrated that the impact of climate change on vegetation has certain temporal effects, including cumulative and time-lag effects (Penuelas \& Filella 2001; Bertrand et al. 2011; Mulder, Iles \& Rockwell 2017; Kong et al. 2020). Cumulative effects represent that climate factors are continuously dynamic, and their impact on vegetation is cumulative and 
chronic over a period of time (Xu et al. 2013). Time-lag effects refer to the vegetation response to previous rather than current climate factors, as terrestrial ecosystems are resilient to external factors (Willis, Jeffers \& Tovar Ingar 2018). Once cumulative and time-lag effects are considered, the analysis of the impact on climate factors on vegetation activities can be assessed in greater detail (Wu et al. 2015; Wen et al. 2019). The accomplishment of vegetation life-stage transitions requires the cumulated temperature to reach a certain threshold, and this threshold affects leaf onset, offset and flowering (Piao et al. 2015; Gonzalez-Suarez, Walker \& Bennett 2020). Moreover, the impact of temperature on vegetation generally lags, and the phenological characteristics of vegetation in spring are mainly determined by the temperature of the last winter, as heat penetration into the soil takes time ( $\mathrm{Xu}$ et al. 2013; Ettinger et al. 2020). Cumulative PRE also greatly affects vegetation activities, and correlations between vegetation and cumulated PRE are strongly reflected in the distribution of plant biomes and ecosystem complexes, especially in arid regions (Guerschman et al. 2020). Zeng et al. (Zeng et al. 2013) indicated that more than $80 \%$ of vegetation variation could be explained by cumulative PRE in some arid regions. The time-lag effects of PRE mostly represent vegetation in semiarid and semi-humid regions, as the vegetation in those regions has the ability to adapt to variations in moisture and is unable to respond quickly (Vicente-Serrano et al. 2013). Cumulative SR is closely associated with vegetation distribution patterns and plant biomes at the global scale and is the main reason for the vegetation latitudinal gradient. It has been reported that a reduction in SR contributes to the primary negative effects of climate change on vegetation (Chen et al. 2021). 
Notably, cumulative SR is the dominant climate driving force affecting vegetation activities in cold ecosystems (Wu et al. 2015).

Siberia is located in the arctic and sub-arctic; it has a typical cold ecosystem and features vegetation structure and species composition gradients (Montesano et al. 2016). As the main plant biomes across Siberia, taiga and tundra are among the most valuable and sensitive environmental zones on Earth (Callaghan et al. 2002; Walther et al. 2019). Taiga and tundra have undergone significant changes in recent decades, so it is meaningful to assess them as clear examples of the influence of climate change on terrestrial ecosystems (Myers-Smith et al. 2020). With climate warming, potential drivers of vegetation greenness in this region include permafrost, land cover, topography, and fire (Berner et al. 2020). Previous studies have enriched our knowledge of the climate factors related to vegetation activities across Siberia. Nevertheless, most of those studies have been centred on simultaneous climate conditions, ignoring cumulative and time-lag effects. For this reason, the details of the vegetation response to climate factors in scenarios of potential cumulative and time-lag effects remain less understood.

To address the abovementioned issues, we explore the relationships between vegetation and climate factors in the context of cumulative and time-lag effects, seeking to 1) determine whether the cumulative and time-lag effects combine to impact vegetation growth and 2) evaluate the sensitivity of vegetation to climate factors at different time scales. Therefore, we chose LST, PRE and SR to represent the climate driving force and the (EVI) to represent the vegetation activities. Random forest regression was fitted to 
evaluate the relationship between climate factors and vegetation under four scenarios: based on simultaneous climate factors, considering cumulative effects, or/and considering time-lag effects of climate factors. Finally, the relative importance of climate factors on vegetation growth was obtained.

\section{Data and methods}

\subsection{Vegetation index data}

In recent decades, remote sensing has emerged as an effective tool in the dynamic monitoring of vegetation over larger areas, making it possible to indicate the health and density of vegetation through the measurement of solar-induced chlorophyll fluorescence (Guanter et al. 2012). Based on satellite land observation data, many vegetation indices have been proposed, such as the normalized vegetation difference index (NDVI) (Deering, Eck \& Banerjee 1999), vegetation condition index (VCI) (Kogan 1995a), vegetation health index (VHI) (Kogan 1995b), and temperature and vegetation dryness index (TVDI) (Sandholt, Rasmussen \& Andersen 2002). Among those indices, the NDVI, as the most widely used, is a normalized ratio of the nearinfrared and red visible bands and is calculated directly without any assumptions regarding environmental conditions. The major disadvantage of the NDVI is the influence of additive noise effects, such as those caused by aerosols (Huete et al. 2002). Considering the wavelength dependency of aerosol effects, Huete et al.(2002) proposed the EVI, which uses the more atmosphere-sensitive blue band to correct the red band to eliminate the aerosol influence. The EVI is a normalized vegetation index with a value ranging from 0 to 1 , calculated by the following equation: 


$$
E V I=G \frac{\rho_{\text {NIR }}-\rho_{\text {red }}}{\rho_{\text {NIR }}+C_{1} \times \rho_{\text {red }}-C_{2} \times \rho_{\text {blue }}+L}
$$

where $\rho_{\text {NIR }}, \rho_{\text {red }}$ and $\rho_{\text {blue }}$ are the near-infrared, red band and blue band reflectance, respectively. These three factors have been atmospherically corrected or partially atmosphere corrected; $\mathrm{G}$ is the gain factor and equals 2.5 ; $\mathrm{L}$ is the canopy background adjustment and equals 1; and $C_{1}$ and $C_{2}$ are the coefficients of the aerosol influences in the red band, which uses the blue band to correct and is equal to 6 and 7.5, respectively.

The EVI is significantly correlated with photosynthetic activities and chlorophyll contents and has been widely used in research on biophysical and structural vegetation properties and spatial/temporal variations (Seddon et al. 2016; Li \& Xiao 2020). In this study, we used the MOD13C2 version 6 product, which provides the monthly global distribution of the EVI at a $0.05^{\circ}$ spatial resolution. Moreover, any pixels with an EVI below 0 were removed because there was no vegetation cover there. The growing season lasts from April to September since the mean temperature in these months is above $0^{\circ} \mathrm{C}$.

\subsection{Meteorological data}

Vegetation activities are limited by both energy conditions and water availability (Beer et al. 2010). LST indicates the combined results of surface-atmosphere interactions and energy fluxes, and it is a considerable surface parameter in terms of driving boundary layer processes (Good et al. 2017). In this paper, we used the MOD11C3 version 6 product, which provides the monthly global land surface temperature at a $0.05^{\circ} \mathrm{C}$ 
resolution. The product has been verified by 42 carefully selected sites around the world and is more accurate than the previous version (Wan 2008). PRE data provided by Integrated Multisatellite Retrievals for Globe Precipitation Measurement (GPM) was used as an indicator of water availability in this work. The GPM is a transformation of the Tropical Rainfall Measuring Mission (TRMM). In addition to the heavy and moderate rainfall that TRMM observes, GPM is capable of capturing light rain and snowfall (Arshad et al. 2021). Furthermore, the GPM orbit covers latitudes ranging $65^{\circ} \mathrm{S} \sim 65^{\circ} \mathrm{N}$. SR is the major energy received by global terrestrial ecosystems and is strongly correlated with vegetation activities (Y1ldırım, Teke \& Antonanzas-Torres 2018). In this work, SR was derived from the Watch Forcing Data methodology applied to the ERA-Interim (WFDEI) reanalysis dataset (Weedon et al. 2018). Based on the three-hour SR provided by the dataset, we calculated the daily SR of each month. Moreover, PRE and SR data were resampled from $0.1^{\circ}$ and $0.5^{\circ}$ to $0.05^{\circ}$ by bilinear interpolation, respectively, the same as the spatial resolution of other data.

\subsection{Land cover data}

Land cover represents the ecosystem surface canopy and vegetation communities, and different vegetation communities have diversified biophysical and biochemical processes. The land cover data used here were obtained from the MODIS land cover product (MCD12C1) (Friedl et al. 2010). The product contains 13 classification schemes of global land cover maps at a $0.05^{\circ}$ resolution. We adopted the classification schemes of the leaf area index (LAI), as our work is mainly related to vegetation. The LAI classification contains 10 land cover categories: 7 categories of natural vegetation, 
water body, non-vegetated land and built-up land. The land cover categories that occupied more than $1 \%$ of the total area were retained (Table 1). Furthermore, the pixels with changed land cover were discarded. Siberia is mainly occupied by savannas and grasslands, which account for $50.33 \%$ and $21.53 \%$ of the total area, respectively. Savannas are distributed primarily in north-eastern Siberia, while grasslands are distributed in southwestern Siberia. Forests are mainly needleleaf, covering $15.05 \%$ of the area (Figure 1).

Table 1 Land cover categories used in this work

\begin{tabular}{ccc}
\hline Land cover & Description & Area percent $(\%)$ \\
\hline Grasslands & Dominated by herbaceous annuals $(<2 \mathrm{~m})$ including cereal croplands. & 21.53 \\
Shrublands & Shrub $(1-2 \mathrm{~m})$ cover $>10 \%$. & 7.09 \\
Savannas & Between 10 and $60 \%$ tree cover $(>2 \mathrm{~m})$. & 50.33 \\
Deciduous Broadleaf Forests & Dominated by deciduous broadleaf trees $(>2 \mathrm{~m})$. Tree cover $>60 \%$. & 3.54 \\
Evergreen Needleleaf Forests & Dominated by evergreen conifer trees $(>2 \mathrm{~m})$. Tree cover $>60 \%$. & 10.81 \\
Deciduous Needleleaf Forests & Dominated by deciduous larch trees $(>2 \mathrm{~m})$. Tree cover $>60 \%$. & 4.25 \\
\hline
\end{tabular}

Note: water bodies and land cover types occupying less than $1 \%$ are excluded.

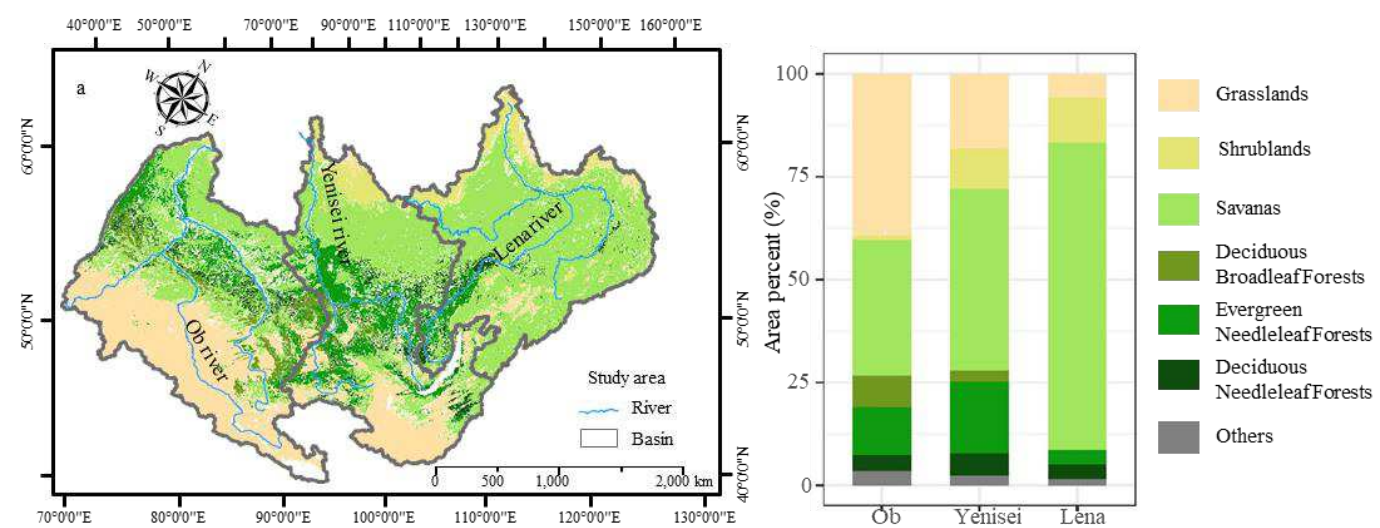

Fig. 1. Spatial distribution of stable land cover of Siberia during 2001-2016 (a), the area percent occupied by each land cover in different basins (b). 

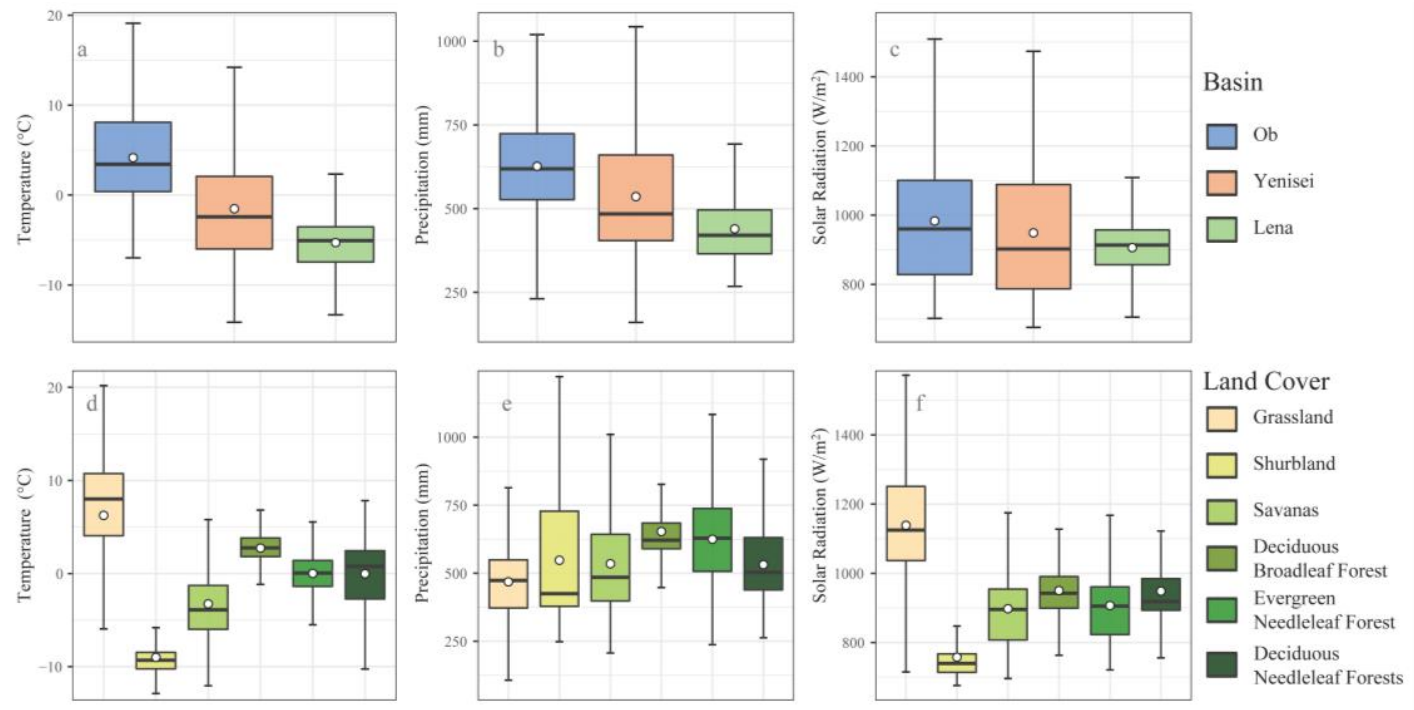

Fig. 2. The difference in climate factors among each basin and land cover category Note: the upper and lower bounds of the whiskers indicate the maximum and minimum, respectively; the lower, middle and upper bounds of the box indicate the 1st, 2nd and 3rd quartiles, respectively; the dot in each box indicates the mean.

There were differences in climate factors among different basins and land cover categories. The overall trends of temperature, PRE and SR decreased from west to east. The mean annual temperature, $\mathrm{PRE}$ and $\mathrm{SR}$ of $\mathrm{Ob}$ were $2.90^{\circ} \mathrm{C}, 632.77 \mathrm{~mm}$ and 977.92 $\mathrm{W} / \mathrm{m}^{2}$, respectively, followed by Yenisei $\left(-2.45^{\circ} \mathrm{C}, 537.97 \mathrm{~mm}\right.$ and $950.43 \mathrm{~W} / \mathrm{m} 2$, respectively) and Lena $\left(-6.38^{\circ} \mathrm{C}, 440.79 \mathrm{~mm}\right.$ and $903.36 \mathrm{~W} / \mathrm{m} 2$, respectively). The changes in annual temperature were consistent with the SR among each land cover category: the maximum was found in grasslands $\left(5.25^{\circ} \mathrm{C}, 1138.65 \mathrm{~W} / \mathrm{m} 2\right)$, followed by deciduous needleleaf forests $\left(1.74^{\circ} \mathrm{C}, 950.08 \mathrm{~W} / \mathrm{m} 2\right)$; the minimum was found in shrublands $\left(-10.01^{\circ} \mathrm{C}, 757.47 \mathrm{~W} / \mathrm{m} 2\right)$, followed by savanna $\left(-4.26^{\circ} \mathrm{C}, 897.51 \mathrm{~W} / \mathrm{m} 2\right)$. The maximum annual PRE was $653.39 \mathrm{~mm}$ in deciduous broadleaf forests, followed by deciduous needleleaf forests $(624.81 \mathrm{~mm})$; the minimum was $468.60 \mathrm{~mm}$ in grasslands, followed by evergreen needleleaf forests $(531.24 \mathrm{~mm})$. 


\subsection{Analysis}

The EVI, LST, PRE and SR were linearly detrended before analysis to reduce the impacts of temporal autocorrelation between vegetation and climate factors. The cumulative effects were analysed under 1-, 3-, 6- and 12-month time scales, and the time-lag effects were analysed under 0-, 1-, 2- and 3-month time scales according to other studies (Wu et al. 2015; Wen et al. 2019; Ding, Li \& Peng 2020). In this study, the climate variables were computed by the following equations:

$$
\begin{aligned}
A T_{T E M(m, i, j)} & =\sum_{k=1}^{i} T E M_{(m-i-j)}, i \in(1,3,6,12), j \in(0,1,2,3) \\
A T_{P R E(m, i, j)} & =\sum_{k=1}^{i} P R E_{(m-i-j)}, i \in(1,3,6,12), j \in(0,1,2,3) \\
A T_{S R_{(m, i, j)}} & =\sum_{k=1}^{i} S R_{(m-i-j)}, i \in(1,3,6,12), j \in(0,1,2,3)
\end{aligned}
$$

where $i$ and $j$ are the cumulative duration and time-lag period of a given climate factor, respectively, and $m$ is April to September from 2000 to 2016, consistent with the meaning below. For instance, $A T_{-} T E M_{(2001-4,3,2)}$ is the sum of $T E M_{(2000-12)}$, $\operatorname{TEM}_{(2001-1)}$ and $\operatorname{TEM}_{(2001-2)}$.

Random forest regression was applied to fit the relationship between the vegetation and climate factors. As one machine learning algorithm, random forest is based on regression tree analysis and has many properties: the ability to fit models with various types of data, the ability to fit nonlinear relationships, the ability to ignore the interaction or collinearity between variables, and even the ability to ignore missing values. Random forest regression creates a set of regression trees, and the output of the 
model is the average of the predictions of all regression trees. In this study, a random forest regression model of each pixel was built through the Randomforest package of the $\mathrm{R}$ project, and the number of regression trees was 500. Furthermore, the coefficient of determination $\left(\mathrm{R}^{2}\right)$ and relative importance $(\mathrm{RI})$ of each climate factor in each pixel were analysed to capture the key time scale (KTS) and key relative importance (KRI). Based on the results, the response of vegetation to climate variables was evaluated.

$$
\begin{aligned}
& E V I_{m}=f\left(A T_{T E M(m, i, j)}, A T_{P R E(m, i, j)}, A T_{S R(m, i, j)}\right),\left(i, i^{\prime}\right) \in(1,3,6,12),\left(j, j^{\prime}\right) \in(0,1,2,3) \quad 5 \\
& R_{\left(i^{\prime}, j^{\prime}\right)}^{2}=\max \left(R_{(i, j)}^{2}\right) \\
& \begin{array}{ll}
K T S=\left(i^{\prime}, j^{\prime}\right) & 7
\end{array} \\
& K R I_{T E M}=R I_{T E M}\left(i^{\prime}, j^{\prime}\right) \\
& K R I_{P R E}=R I_{P R E\left(i^{\prime}, j^{\prime}\right)} \\
& K R I_{S R}=R I_{S R\left(i^{\prime}, j^{\prime}\right)} \quad 10
\end{aligned}
$$

where $i^{\prime}$ and $j^{\prime}$ are the key time scales of cumulative duration and time-lag period, respectively. All statistical analyses of the data in this research were carried out using $\mathrm{R}$ project, and image processing was conducted in ArcGIS 10.2. 


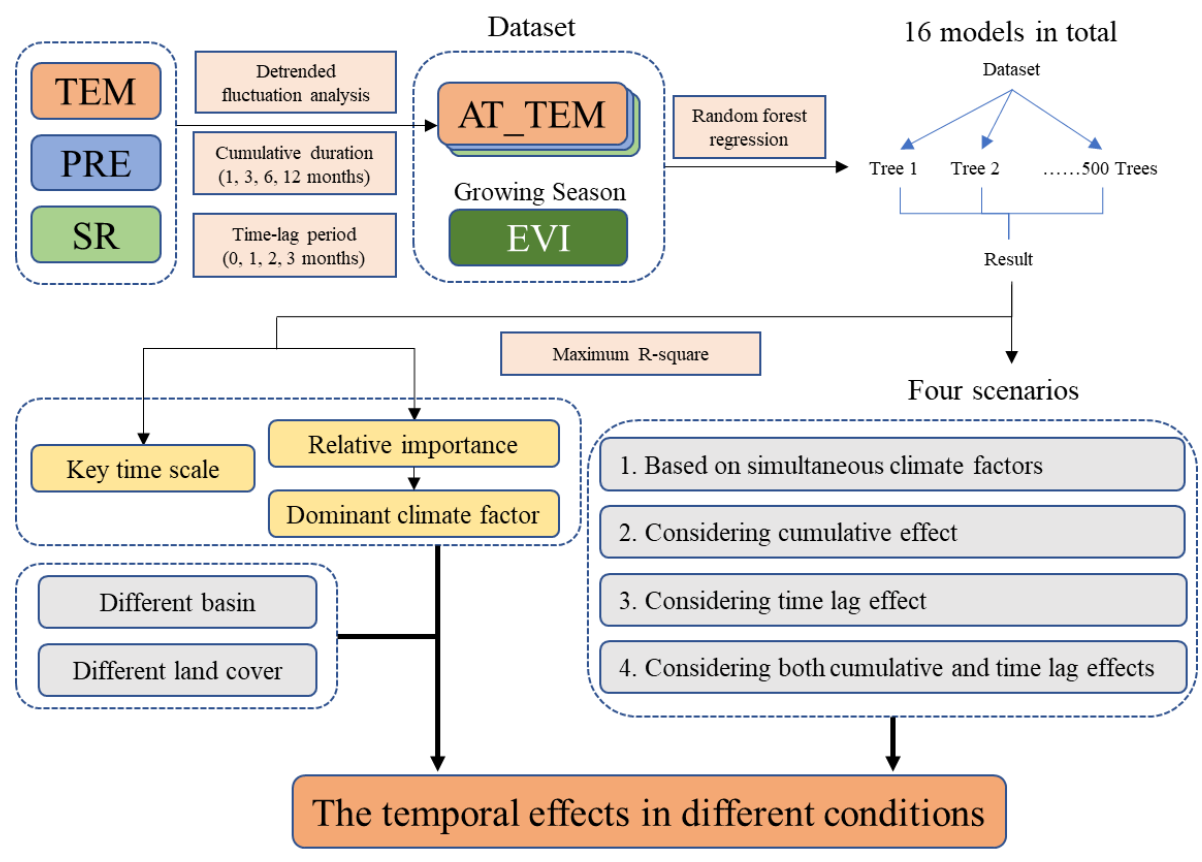

Fig. 3. Flow chart of the algorithm used to analyse the temporal effects.

\section{Result}

\subsection{Greening of Siberia}
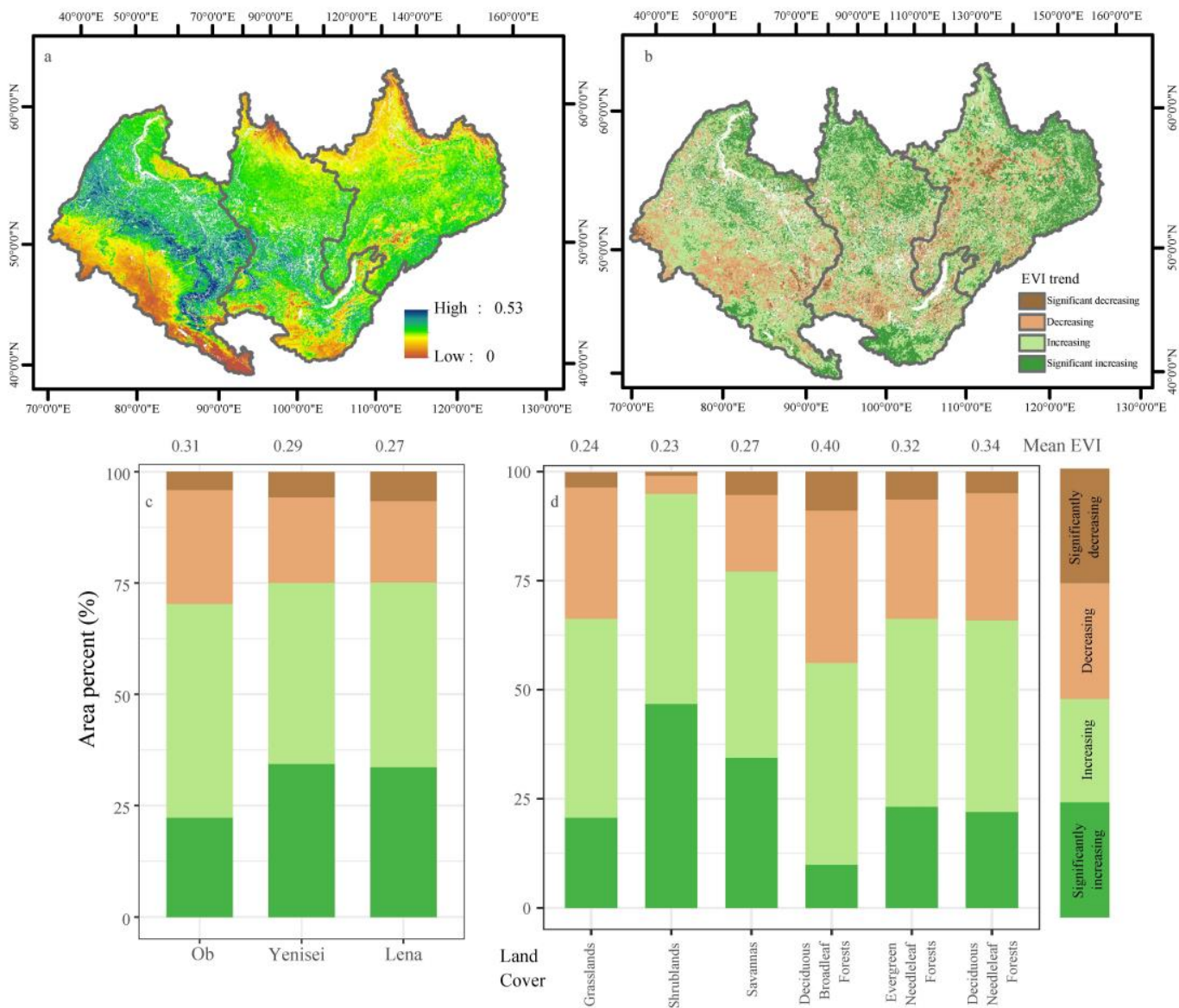
Fig. 4. Spatial distribution of the mean growing season EVI (a) and the trend (b) during 2000-2016. The area percent of different range EVI trends in each basin (c) and land cover category (d). Note: the mean EVI is provided above each bar.

The mean EVI in the growing season was 0.29 in Siberia, and its spatial distribution showed a significant decrease from the $\mathrm{Ob}$ basin $(0.31)$ to the Lena basin $(0.27)$. The EVI also varied with land cover categories; the maximum value was found in deciduous broadleaf forests $(0.40)$, followed by deciduous needleleaf forests $(0.34)$, evergreen needleleaf forests $(0.32)$, and savannas $(0.27)$, and the minimum value was found in shrublands (0.23). During 2000-2016, the mean EVI of the growing season showed an increase within $73.32 \%$ of the area with a mean trend of $0.014 / 10 \mathrm{a}$, and a significant increase was observed in $29.79 \%$ of the area. The decreasing trends occurred in $26.68 \%$ of the area, mainly in the southeast of the Ob basin and in the middle of the Lena basin; however, only $5.48 \%$ of the area of Siberia showed a significant decrease in the EVI. The overall trend of the EVI increased among all land cover categories, with shrublands exhibiting the most obvious changes and broadleaf forest exhibiting the least obvious changes.

Furthermore, we randomly created 1000 points and extracted the corresponding mean growing season EVI, mean annual LST, PRE and SR. The results are depicted in Fig. 5, and locally weighted regression was applied to fit the curve. The relationships of the EVI and climate factors were nonlinear. The LST showed a positive effect on the EVI when the mean annual LST was below $2^{\circ} \mathrm{C}$ and a negative effect when the mean annual LST was greater than $2{ }^{\circ} \mathrm{C}$. The relationship between the EVI and PRE turned from 
positive to negative when the mean annual PRE exceeded $650 \mathrm{~mm}$. Furthermore, the EVI performed best when the mean annual SR was $950 \mathrm{w} / \mathrm{m}^{2}$, and it decreased at other SR values.
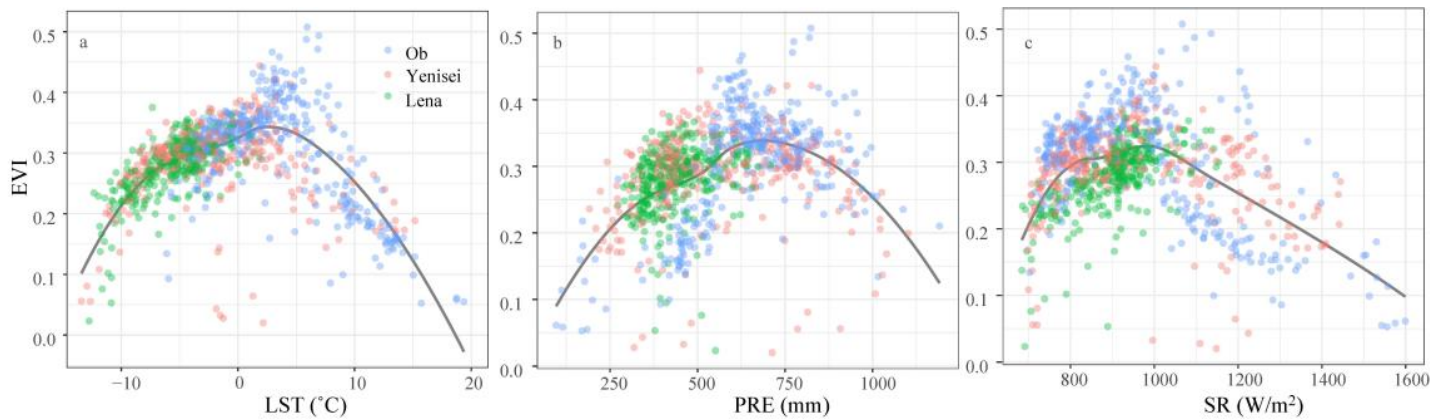

Fig. 5. The relationship between the EVI and LST (a), PRE (b) and SR (c) across Siberia.

\subsection{Cumulative and time-lag effects}

A random forest regression model was applied to fit the relationship between vegetation and climate factors. To enhance our knowledge of the mechanisms of vegetation response to climate factors, we analysed four scenarios: 1. Based on simultaneous climate factors (Fig. 6-a); 2. Considering the cumulative effects of climate factors (Fig. 6-c, d); 3. Considering the time-lag effects of climate factors (Fig. 6-e, f); and 4. Considering both cumulative and time-lag effects of climate factors (Fig. 6-g, h). The $\mathrm{R}^{2}$ and corresponding time scale of each pixel were obtained according to the result of random forest regression of the EVI and climate factors in each scenario. In the random forest regression model, $\mathrm{R}^{2}$ represents the ability of the model to explain the variation, indicating the sensitivity of vegetation to climate change.

The distribution of $\mathrm{R}^{2}$ performance was divergent when the EVI was small and tended to be gradually flatten with increasing EVI, which indicated that the random forest 
regression model was more suitable in areas with good vegetation (Fig. 6-b). Fig. 6 shows the spatial distribution of $\mathrm{R}^{2}$ and the corresponding time scale of the four scenarios. The 0.71 variation in vegetation across Siberia could be explained by simultaneous climate factors, and the weak performance of the model was mainly concentrated in the southwestern $\mathrm{Ob}$ basin, indicating that the vegetation in this area was greatly affected by factors other than climate factors (Fig. 6-a). The consideration of cumulative effects of climate factors increased the $\mathrm{R}^{2}$ to 0.73 , and no cumulative effects were observed in $68.39 \%$ of the area, followed by A3T0 (A3T0 means cumulative duration is three months and time-lag period is zero month, same as the rest, $15.46 \%$ ) and A6T0 (15.90\%); additionally, A12T0 accounted for only $0.25 \%$ of the area (Fig. 6-b, c). The consideration of the time-lag effects of climate factors increased the ability to explain the vegetation variation to 0.74 , and no time-lag effects were observed in $65.63 \%$ of the area, followed by A1T3 (39.45\%), A1T1 and A1T2, which occupied $6.03 \%$ and $1.29 \%$, respectively (Fig. 6-d, e). When considering both cumulative and time-lag effects, we obtained a mean $\mathrm{R}^{2}$ of 0.77 , A1T0 was observed in $19.42 \%$ of the area, and $80.58 \%$ showed cumulative and/or time-lag effects (Fig. 6-f, g). 

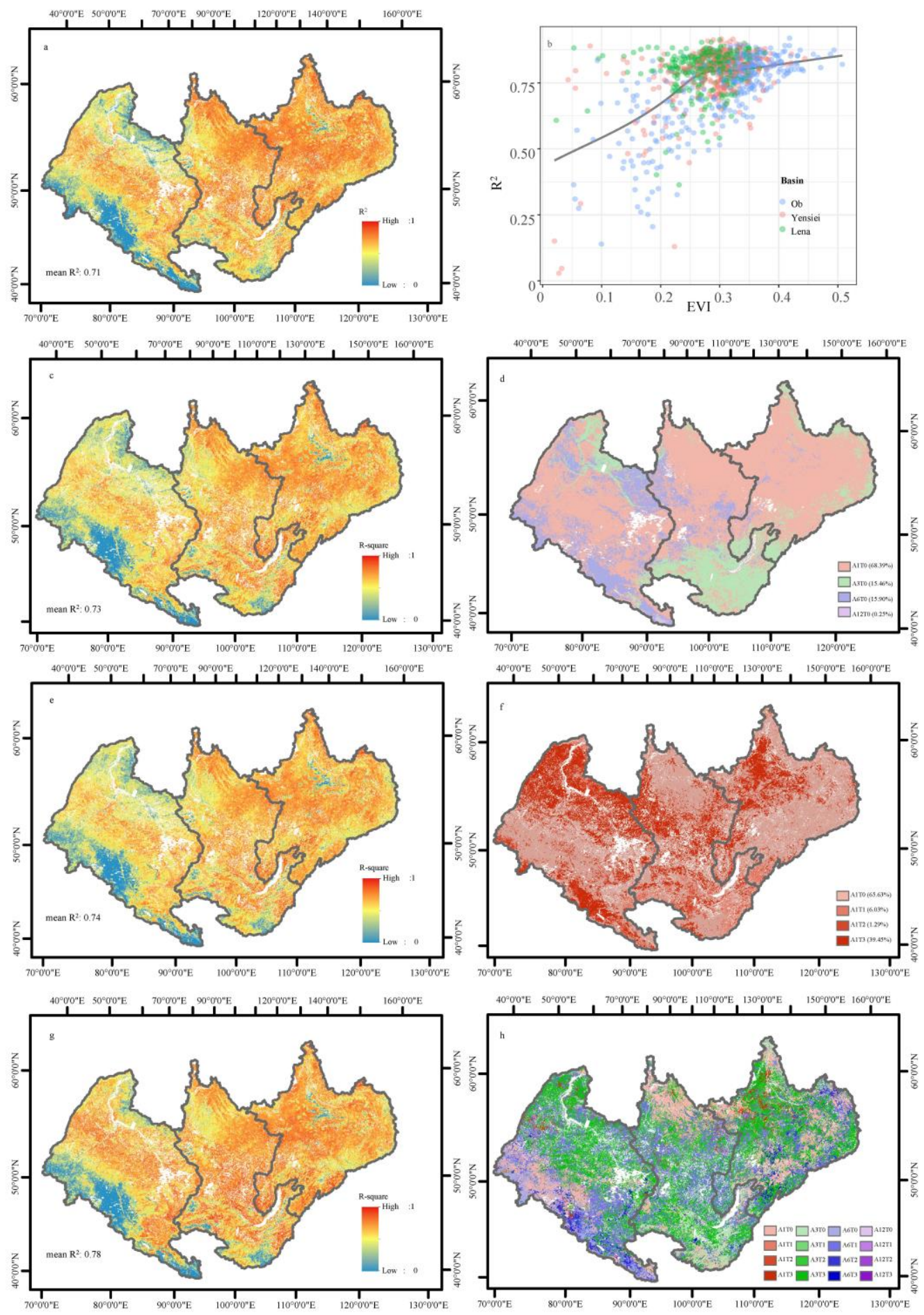

Fig. 6. Spatial distribution of the $\mathrm{R}^{2}$ of random forest regression under four scenarios (a, c, e, g) and the corresponding time scale of cumulative duration and time-lag period $(d, f, h)$. The relationship between the EVI and $R^{2}(b)$.

Note: A1T0 in figure b means cumulative duration is one month and the time-lag period is zero months, same as the rest. 
Further results were obtained based on the scenarios of considering both cumulative and time-lag effects. The spatial distribution of $\mathrm{R}^{2}$ increased from west to east, with an overall average of $0.72 \pm 0.13$ in the $\mathrm{Ob}$ basin, $0.79 \pm 0.08$ in the Yenisei basin and 0.80 \pm 0.07 in the Lena basin. The $\mathrm{R}^{2}$ also varied with land cover categories, performing well in deciduous needleleaf forests $(0.84 \pm 0.04)$ and deciduous broadleaf forests $(0.82$ $\pm 0.04)$, followed by that in evergreen needleleaf forests $(0.81 \pm 0.06)$, savannas $(0.79$ $\pm 0.08)$, shrublands $(0.79 \pm 0.06)$; the weakest value was found in grasslands $(0.68 \pm$ $0.13)$.

Table 2 lists the area percent occupied at each time scale. Climate factors have both cumulative and time-lag effects on vegetation in most areas $(80.58 \%)$. The vegetation in Siberia showed an average cumulative duration of $3.61 \pm 1.97$ months and a timelag period of $1.51 \pm 1.20$ months. Vegetation was more sensitive to 3-month (42.22\%) and 6-month (36.64\%) cumulative durations of climate factors and less sensitive to 12 months $(0.28 \%)$; furthermore, no cumulative effects were observed in $22.86 \%$ of the area (cumulative duration is 1 month), which indicated that vegetation hardly responded to cumulative climate factors with a duration greater than 6 months. The time-lag effects were mainly manifested in a period of 3 months (33.28\%), followed by 1 month (28.46\%) and 2 months (11.61\%), and $26.65 \%$ of the area exhibited no time-lag effects (time-lag effects period was 0 months). The duration of the time lag generally varied with different cumulative durations: the no time lag effect area mainly corresponded to 1-month cumulative effects (A1T0), which indicated that the response of vegetation to climate was immediate in those pixels; additionally, 1-month time lag effects 
corresponded to 6-month cumulative effects (A6T1), and 2- and 3-month time lag effects corresponded to 3-month cumulative effects (A3T2 and A3T3).

Table 2 The area percent of different cumulative and time-lag effects

\begin{tabular}{|c|c|c|c|c|c|c|}
\hline \multicolumn{2}{|c|}{ Area percent } & \multicolumn{4}{|c|}{ Cumulative (month) } & \multirow{2}{*}{ Total } \\
\hline$(\%)$ & & 1 & 3 & 6 & 12 & \\
\hline \multirow{4}{*}{ 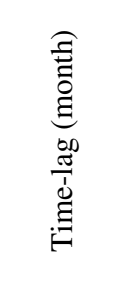 } & 0 & 19.42 & 4.56 & 2.54 & 0.12 & 26.65 \\
\hline & 1 & 0.43 & 0.18 & 27.81 & 0.03 & 28.46 \\
\hline & 2 & 0.07 & 9.39 & 2.11 & 0.04 & 11.61 \\
\hline & 3 & 2.94 & 28.09 & 2.18 & 0.07 & 33.28 \\
\hline \multicolumn{2}{|l|}{ Total } & 22.86 & 42.22 & 34.64 & 0.28 & 100.00 \\
\hline
\end{tabular}

The cumulative and time lag effects of climate factors on vegetation were also different with basins and land cover categories. The average cumulative duration was $3.99 \pm 2.02$ months in the $\mathrm{Ob}$ basin, $3.53 \pm 1.91$ months in the Yenisei basin, and 3.26 \pm 1.91 months in the Lena basin; additionally, the average time-lag periods were $1.55 \pm 1.18$ months, $1.38 \pm 1.16$ months and $1.60 \pm 1.26$ months, respectively. Grasslands and shrublands were sensitive to short-term climate factors. No time-lag effects were observed in $49.75 \%$ of grasslands, which revealed that the impact of climate factors on vegetation was immediate in those locations. Furthermore, A1T0 occurred in $51.67 \%$ of shrublands, indicating that vegetation activity was generally synchronized with climate factor variation. The average time-lag period was lowest in grasslands (0.96 \pm 1.14 months), followed by that in shrublands $(0.96 \pm 1.26$ months $)$; moreover, the cumulative duration was $3.69 \pm 2.19$ months and $2.36 \pm 1.74$ months, respectively. Forests obviously responded to the long-term effect of climate factors, as A3T3 and A6T1 occupied over $65 \%$ of the broadleaf and needleleaf forests, respectively. The average cumulative 
duration was highest in evergreen needleleaf ( $4.15 \pm 1.65$ months), followed by that in deciduous needleleaf $(3.95 \pm 1.73$ months $)$ and deciduous broadleaf $(3.89 \pm 1.94$ months), and the time-lag periods were $1.89 \pm 0.96,1.87 \pm 1.07$ and $1.75 \pm 1.15$ months, respectively. The savanna vegetation response to climate factors was between that observed for grasslands and forests, with an average cumulative effect of $3.52 \pm 1.90$ months and an average time-lag effect of $1.68 \pm 1.19$ months; additionally, the response was most sensitive to A3T3 (32.24\%), followed by A6T1 (27.67\%) and A1T0 (18.47\%).
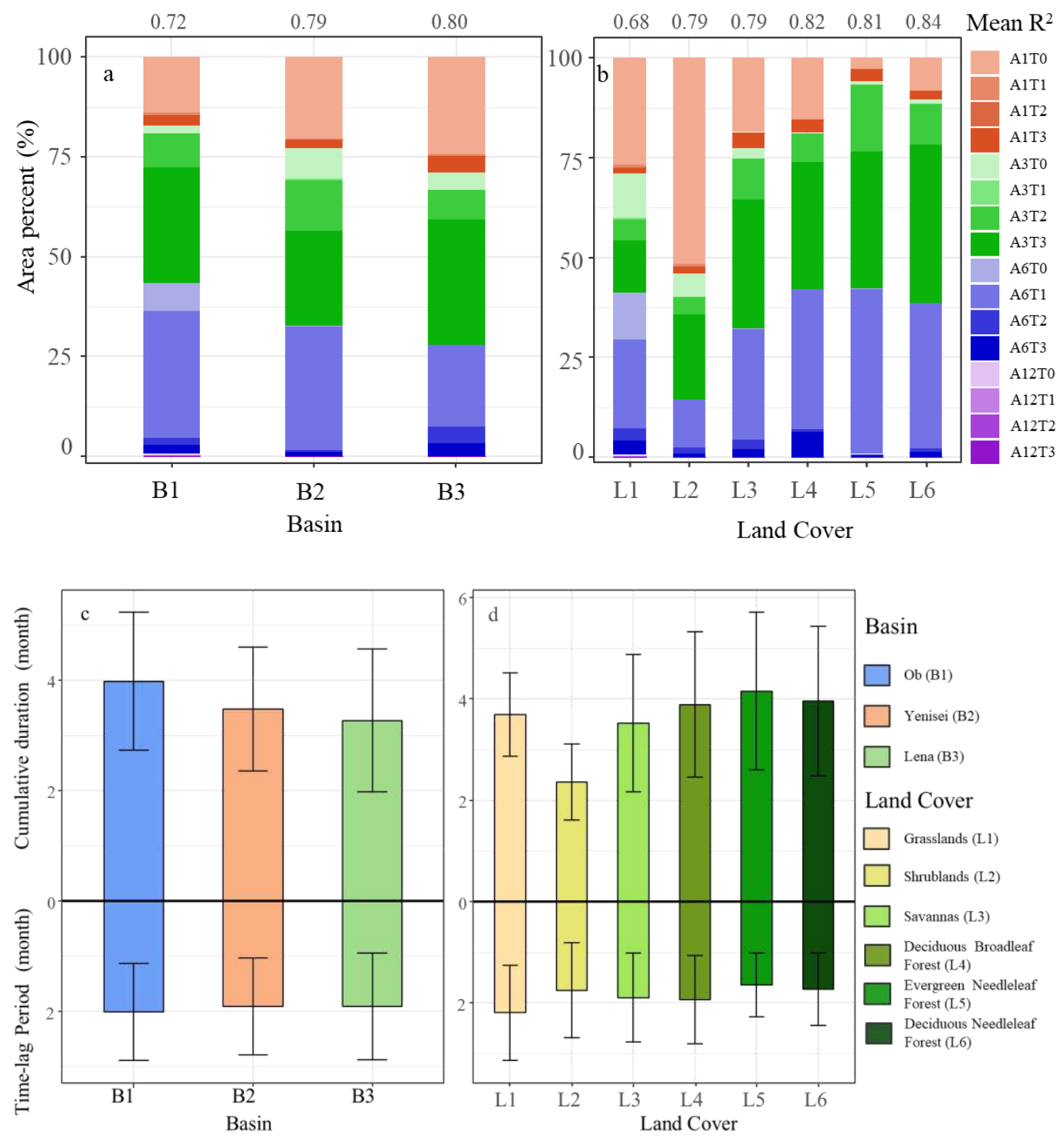

Fig. 7. The area percent occupied by each time scale $(a, b)$, the cumulative duration 
(upper of c, d) and the time-lag period (lower of c, d) of each basin (a, c) and land cover category $(b, d)$.

Note: the bounds of the boxes in c-f indicate the mean and mean \pm standard deviation.

\subsection{Relative importance of climate factors}

According to the key time scale of each pixel, the relative importance of LST, PRE and SR were extracted. Across Siberia, SR was the leading climate driver, followed by LST, and PRE was the least important. The mean SR relative importance was 28.84 , and SR was the dominant climate factor (SR relative importance was the highest among the pixels) in $55.95 \%$ of the area, mainly distributed in the $\mathrm{Ob}$ basin and in the south of Yenisei basin. The mean relative importance of LST was 27.86, and LST was observed as the dominant climate factor in $41.28 \%$ of the area, concentrated in the Lena basin and in the north of the Yenisei basin. The mean relative importance of PRE was 11.83, and the pixels dominated by PRE occupied only $2.78 \%$ of the area (Fig. 8-a, b), spreading in the north of the $\mathrm{Ob}$ basin and the Yenisei basin.

Fig. 8 shows the relative importance of climate factors at different time scales and among land cover categories. Across Siberia, the total area occupied by A1T0 (19.42\%), A3T2 (9.39\%), A3T3 (28.09\%) and A6T1 (27.81\%) reached $84.71 \%$ of the whole region, and the relative importance of climate factors in those areas was slightly different: the range of mean SR importance was from 26.05 to 30.39 ; the range of mean LST importance was from 25.91 to 30.28 ; and the range of mean PRE importance was from 10.09 to 12.07 (Fig. 8-c). The order of relative importance of climate factors in different land cover categories was similar, which showed that SR was the most 
important and PRE was the least important. Only in shrublands was LST more important than SR and became the main climate driving factor (Fig. 8-d).
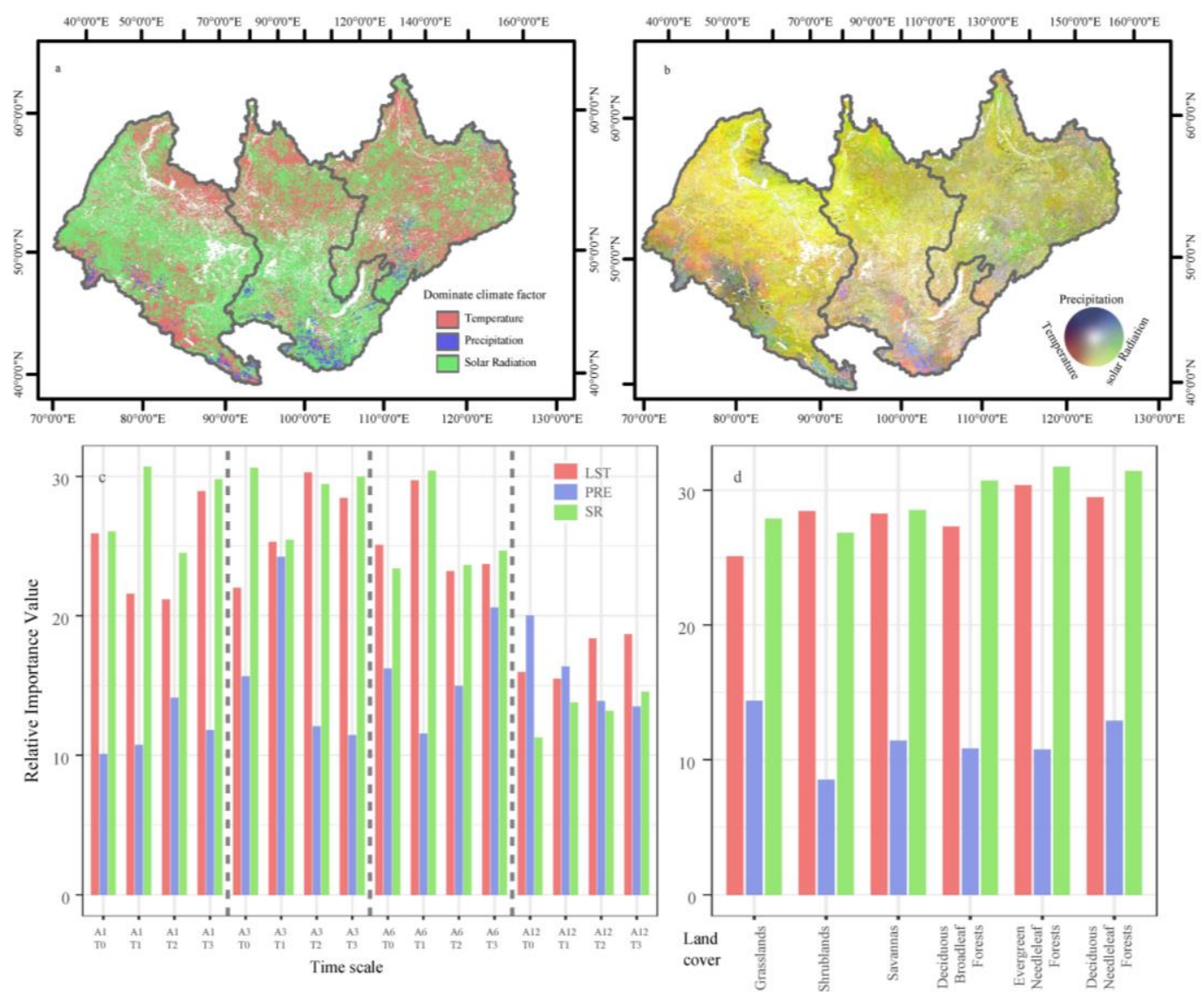

Fig. 8. Spatial distribution of the dominant climate factor of the EVI (a) and RGB composite map of the relative importance of climate factors (b). The relative importance of climate factors at different time scales (c) and among land cover categories (d).

Note: LST, PRE and SR are labelled red, blue and green, respectively. Moreover, the relative importance values of LST, PRE and SR were linearly transformed to the range of 0-255 to complete the map.

\section{Discussion}

Vegetation greenness in Siberia has been observed to increase with climate warming, especially in regions primarily characterized by tundra shrubs, where considerable greening has been reported (Forbes, Fauria \& Zetterberg 2010; Berner et al. 2020). In 
the boreal forests and grasslands, the greening trend was relatively small (Fig. 3-1 d). Since entering the $21^{\text {st }}$ century, a slowing or reversal of apparent greening has been widely reported across Siberia (Bhatt et al. 2013). The ratio of the greening to browning transition from 2000 to 2016 was 5.9:1 in our research, and another study based on 1982-2014 GIMMS NDVI suggested that the ratio was 16.8:1 across boreal and arctic ecosystems (Park et al. 2016). Moreover, the trends of vegetation growth had large spatial heterogeneity (Miles, Miles \& Esau 2019). In northern Siberia, greening was dominant, and its ratio declined with decreasing latitude (Fig. 3-1 b). Such characteristics have also been documented by Mile's research (Miles \& Esau 2016). Loranty et al. (2016) indicated that the variation in vegetation was closely related to the distribution of permafrost, with greening in areas of continuous permafrost and browning in areas of discontinuous permafrost.

Climate change was the primary driving force for vegetation variation in Siberia (Zhu et al. 2016), and the explanation of climate factors increased when cumulative and timelag effects were considered (Fig. 6). In previous studies, Ding et al. (2020) confirmed that the explanation of vegetation growth by climate change would increase from $54 \%$ to $63 \%$ by factoring in the consideration of cumulative and time-lag effects. Wen et al. (2019) compared the results from scenarios considering time-lag effects only and considering both cumulative and time-lag effects and found that the latter would increase the explanation of the model in $77 \%$ of the global area. Moreover, in arctic and north temperate regions, the calculated $\mathrm{R}^{2}$ increased from 0.76 to 0.78 and from 0.74 to 0.77, respectively (Wen et al. 2019). These results indicated that vegetation growth was 
affected by both cumulative and time-lag effects, which improves our understanding of the interaction between vegetation and climate. Furthermore, overcoming many limitations and problems of the linear regression model (Breiman 2001), the random forest regression model is the most commonly used model and has good performance, especially in regions with a high EVI (Fig. 3-A). The model will provide us with new inspiration for the application of machine learning algorithms in geographical research.

The cumulative duration and time-lag period reflect the persistence and resilience of an ecosystem. Our research showed that the short-term cumulative effects generally corresponded to the short-term time-lag effects in each land cover category and vice versa. Moreover, the temporal effects of short time scales corresponded to ecosystems with less function and diversity, such as tundra shrubs. In contrast, the temporal effects at the long-term scale corresponded to complex ecosystems, such as boreal forests (Figs. 3-4). Complex ecosystems always exhibit high climate tolerance due to the collaboration and complementarity of biodiversity (Ehbrecht et al. 2021). Moreover, long-term temporal effects occurred in regions with better climate conditions (Fig. 22). Because the function and diversity of ecosystems are mainly determined by climate, complex ecosystems are generally supported by warm and humid climates (Harrison, Spasojevic \& Li 2020). Our result was not observed in Ding's research, which was explicable, as Ding assumed that the temporal effects of climate on vegetation growth were less than three months, thus ignoring the long-term effects (Ding, Li \& Peng 2020). However, the temporal effects in many semiarid and semi-humid regions have exceeded 3 months, or even 12 months or more (Vicente-Serrano et al. 2013; Büntgen et al. 2015). 
The impact of different climate factors on vegetation varies greatly. Across Siberia, vegetation activities were strongly restricted by SR and temperature and less affected by PRE. Based on the random forest regression model, the mean relative importance of SR was 28.84, and it was the dominant climate factor in $55.95 \%$ of the area. Regional SR mainly depends on latitude, but the actual incoming radiation on the land surface is determined by sunshine duration, atmospheric aerosol, topography and cloudiness. Some studies chose the cloudiness index to characterize incoming photosynthetically active solar radiation (de Jong et al. 2013; Seddon et al. 2016). In high-latitude regions, vegetation activities are driven by a combination of SR and temperature (Seddon et al. 2016; Wen et al. 2019). In our research, SR was slightly more important than temperature. A possible explanation is that vegetation in cold ecosystems has the ability to adapt to low temperatures and the ability to complete photosynthesis processes at lower optimum temperatures. For example, mosses can photosynthesize at temperatures near $-10^{\circ} \mathrm{C}$ and exhibit negative net ecosystem exchange fluxes $(\mathrm{He}, \mathrm{He}$ \& Hyvönen 2016). However, SR is closely associated with light intensity, and when the light intensity is insufficient to reach the light compensation point, the rate of photosynthesis is less than that of respiration, resulting in positive net ecosystem exchange fluxes (Kutzbach, Wille \& Pfeiffer 2007).

Temperature was a key climate factor that restricted vegetation activities in Siberia. The relative importance of temperature was 27.86 , and it was the dominant climate factor in $41.28 \%$ of the area. Previous studies based on remote sensing data or field simulation experiments have provided strong evidence that greening across Siberia is mainly 
driven by warming (Elmendorf et al. 2012; Phoenix \& Bjerke 2016). However, some studies have also indicated that the effect of warming on vegetation depends on soil moisture, with more positive effects in humid regions (Berner et al. 2020). In other cases, changes in surface albedo, permafrost and soil nutrients could also influence the vegetation response to warming and even affect the key environmental constraints that limit vegetation activities (Myers-Smith et al. 2015). The greening speed of Siberia has slowed in recent years (Myers-Smith et al. 2020), which may be due to the negative effect of warming, as warming enhances soil moisture consumption, especially in the middle of the growing season. The reduced leaf water potential caused by low soil moisture leads to stomatal constraints on photosynthesis, and finally, the benefit of ameliorating low temperature limitation on photosynthesis by warming decreases (Comiso \& Hall 2014; Reich et al. 2018). Furthermore, the slowing of warming in the past decade has been regarded as an important reason for the phenomenon (Fyfe et al. 2016; Hedemann et al. 2017).

PRE seems to be less important to vegetation growth in Siberia, with a mean relative importance of only 11.83, although the annual PRE is low across Siberia, especially in the Yenisei basin and Lena basin. However, vegetation in Siberia is seldom restricted by water availability, and the low vapor pressure deficit as the temperature decreases reduces water stress; moreover, the thawing of permafrost in the growing season provides necessary soil moisture for vegetation growth (Anderson et al. 2019). Furthermore, the sensitivity of vegetation to precipitation was different among each plant species. The grasslands of Siberia are concentrated in the north-western region, 
far from the coastline and at lower altitudes. Compared with other land cover categories, vegetation on grasslands was more sensitive to precipitation for high temperatures and low precipitation (Chen et al. 2020). Other land cover categories generally have strong resistance and resilience to water stress, especially in tundra. The vegetation biome is dominated by mosses and lichens, which have the ability to tolerate extreme drying, as they can lose cell water without dying and resume when they obtain appropriate moisture (Robinson et al. 2018). The importance of water availability to vegetation is complex in Siberia, as increasing temperatures would increase the saturated water vapor pressure at a rate of $7 \% / \mathrm{K}$, which will exacerbate the water deficit of vegetation (Yuan et al. 2019), and warming would cause earlier snowmelt, which often results in the drying of surface soils and adversely affects vegetation (Gamon et al. 2013). In contrast, the increasing summer precipitation across most of the arctic region and substantial permafrost thawing would reduce the water deficit that affects vegetation (Douglas, Turetsky \& Koven 2020).
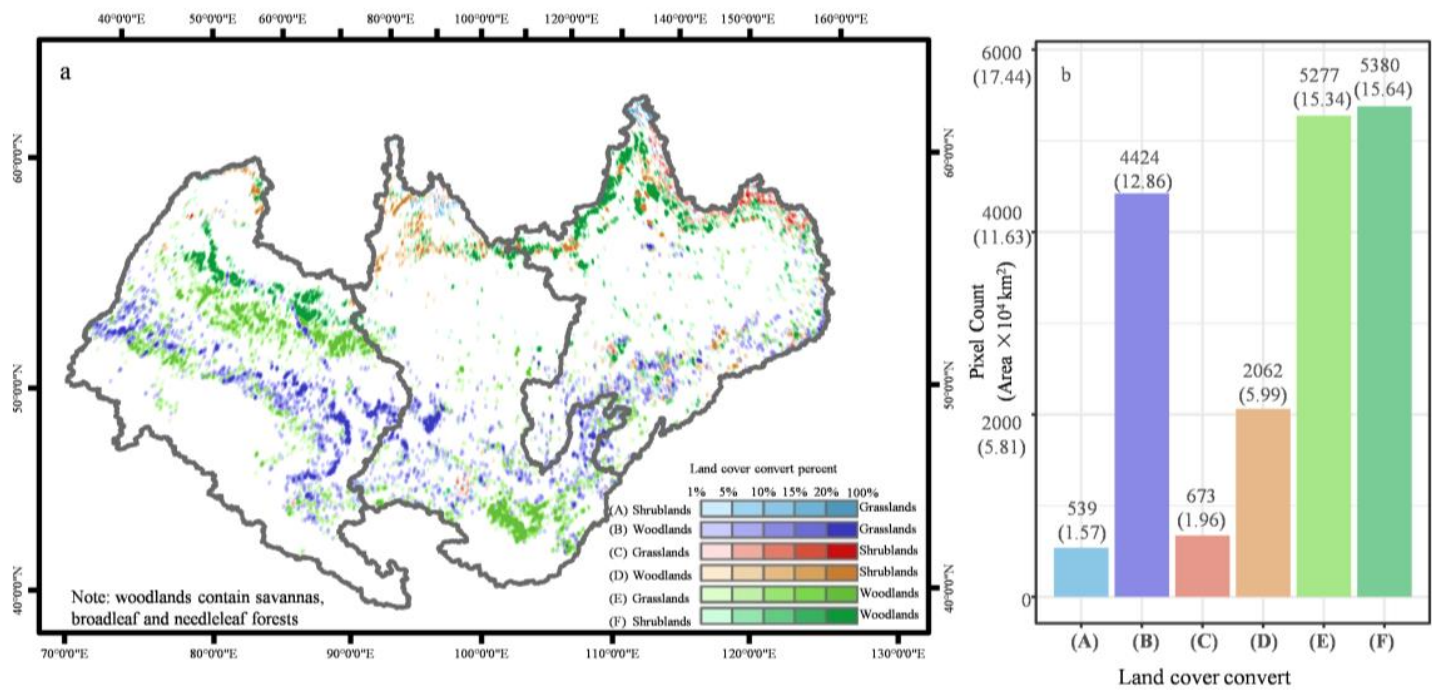

Fig. 9. Land cover conversion in Siberia during 2001-2016. 
The land cover changes in the treeline ecotone in the arctic and subarctic, such as shrub tundra succession and the northward shift of boreal forests, have attracted the attention of several studies (Devi et al. 2008; Holtmeier \& Broll 2019; Walther et al. 2019). During the study period, the major land cover changes in Siberia were the mutual conversions of grasslands and woodlands and the transfer of shrubland to woodlands (Fig. 9). These phenomena have been verified by previous studies, and ongoing warming was considered the dominant factor for dramatic change (Pearson et al. 2013; Miles, Miles \& Esau 2019). Vegetation activities were constrained by both energy conditions and water availability. In the southern boreal forest, warming enhanced the water stress on vegetation and resulted in woodland degradation to grasslands $\left(12.86 \times 10^{4} \mathrm{~km}^{2}\right)$, while in the northern boreal forest, warming improved the energy limitation, with suitable moisture conditions, and the shrublands gradually succeeded in woodlands $\left(15.64 \times 10^{4} \mathrm{~km}^{2}\right)$ (Berner et al. 2013; Myers-Smith et al. 2015). Moreover, in the northern $\mathrm{Ob}$ basin and southern Yenisei basin (high altitude), which are also energy-limited ecosystems, a larger area $\left(15.34 \times 10^{4} \mathrm{~km}^{2}\right)$ of grasslands was converted into woodlands as warming occurred (Aakala et al. 2014; Arekhi et al. 2018). Overall, the forest treeline sharply contracted in the south and expanded in the north, but the total area increased by approximately $12.13 \times 10^{4} \mathrm{~km}^{2}$. Woodlands showed more obvious climate temporal effects than shrublands due to their high ecosystem resilience; hence, the change in land cover across Siberia as warming continues would enhance the climate temporal effects on vegetation.

Notably, only 17a meteorological data points were used in this research. Therefore, the 
results of our research are possibly biased, as the stable result was generally analysed using meteorological data that were more than 30a. The MODIS EVI was used to characterize the vegetation activity in our research. The most common datasets of the vegetation index include the Advanced Very-High-Resolution Radiometer (AVHRR, 1982-present); SPOT Vegetation (SPOT-VEG, 1998-present); Landsat sensors (1972present) and MODIS (2000-present). However, there are significant differences among those datasets due to the inconsistency of satellites (Myers-Smith et al. 2020). Thus, the accuracy of the vegetation index of different datasets should be compared to select the most suitable dataset for Siberia. Furthermore, we did not analyse the difference in temporal effects among climate factors, as strong interactions exist within temperature, SR and PRE (Gan, Liu \& Sun 2021). Nevertheless, the impacts of different climate factors on vegetation are not the same (Nemani et al. 2003; Seddon et al. 2016), and the temporal effects should also be analysed separately to reveal more details of the vegetation response to climate factors.

\section{Conclusion}

In this paper, the cumulative and time-lag effects of climate factors on vegetation in Siberia from 2000-2016were analysed through a random forest regression model. Furthermore, the differences in cumulative and time-lag effects were compared among each basin and land cover category, and the underlying mechanisms were discussed.

This study revealed more details of the temporal effects of climate factors, enriched our understanding of the interaction between vegetation and climate change, and highlighted that the duration of temporal effects corresponded to regional climate 
conditions and ecosystem complexity: long-term temporal effects occurred in relatively warm and humid regions, such as boreal forests, and short-term temporal effects occurred in relatively cold regions, such as tundra shrubs. Moreover, the land cover change caused by warming would enhance the temporal effects.

\section{References:}

Aakala, T., Hari, P., Dengel, S., Newberry, S., Mizunuma, T. \& Grace, J. (2014) A prominent stepwise advance of the tree line in North-East Finland. Journal of Ecology, 102.

Abril, G., Martinez, J.M., Artigas, L.F., Moreira-Turcq, P., Benedetti, M.F., Vidal, L., Meziane, T., Kim, J.H., Bernardes, M.C., Savoye, N., Deborde, J., Souza, E.L., Alberic, P., Landim de Souza, M.F. \& Roland, F. (2014) Amazon River carbon dioxide outgassing fuelled by wetlands. Nature, 505, 395-398.

Anderson, J.E., Douglas, T.A., Barbato, R.A., Saari, S., Edwards, J.D. \& Jones, R.M. (2019) Linking vegetation cover and seasonal thaw depths in interior Alaska permafrost terrains using remote sensing. Remote Sensing of Environment, 233.

Arekhi, M., Yesil, A., Ozkan, U.Y. \& Balik Sanli, F. (2018) Detecting treeline dynamics in response to climate warming using forest stand maps and Landsat data in a temperate forest. Forest Ecosystems, $\mathbf{5}$.

Arshad, M., Ma, X., Yin, J., Ullah, W., Ali, G., Ullah, S., Liu, M., Shahzaman, M. \& Ullah, I. (2021) Evaluation of GPM-IMERG and TRMM-3B42 precipitation products over Pakistan. Atmospheric Research, 249.

Baumbach, L., Siegmund, J.F., Mittermeier, M. \& Donner, R.V. (2017) Impacts of temperature extremes on European vegetation during the growing season. Biogeosciences, 14, 4891-4903. 
Beer, C., Reichstein, M., Tomelleri, E., Ciais, P., Jung, M., Carvalhais, N., Rödenbeck, C., Arain, M.A., Baldocchi, D., Bonan, G.B., Bondeau, A., Cescatti, A., Lasslop, G., Lindroth, A., Lomas, M., Luyssaert, S., Margolis, H., Oleson, K.W., Roupsard, O., Veenendaal, E., Viovy, N., Williams, C., Woodward, F.I. \& Papale, D. (2010) Terrestrial Gross Carbon Dioxide Uptake: Global Distribution and Covariation with Climate. Science, 329, 834.

Berner, L.T., Beck, P.S., Bunn, A.G. \& Goetz, S.J. (2013) Plant response to climate change along the forest-tundra ecotone in northeastern Siberia. Glob Chang Biol, 19, 3449-3462.

Berner, L.T., Massey, R., Jantz, P., Forbes, B.C., Macias-Fauria, M., Myers-Smith, I., Kumpula, T., Gauthier, G., Andreu-Hayles, L., Gaglioti, B.V., Burns, P., Zetterberg, P., D'Arrigo, R. \& Goetz, S.J. (2020) Summer warming explains widespread but not uniform greening in the Arctic tundra biome. Nat Commun, 11, 4621.

Bertrand, R., Lenoir, J., Piedallu, C., Riofrio-Dillon, G., de Ruffray, P., Vidal, C., Pierrat, J.C. \& Gegout, J.C. (2011) Changes in plant community composition lag behind climate warming in lowland forests. Nature, 479, 517-520.

Bhatt, U., Walker, D., Raynolds, M., Bieniek, P., Epstein, H., Comiso, J., Pinzon, J., Tucker, C. \& Polyakov, I. (2013) Recent Declines in Warming and Vegetation Greening Trends over PanArctic Tundra. Remote Sensing, 5, 4229-4254.

Breiman, L. (2001) Random Forests. Machine Learning, 45, 5-32.

Buitenwerf, R., Rose, L. \& Higgins, S.I. (2015) Three decades of multi-dimensional change in global leaf phenology. Nature Climate Change, 5, 364-368.

Büntgen, U., Hellmann, L., Tegel, W., Normand, S., Myers-Smith, I., Kirdyanov, A.V., Nievergelt, D., Schweingruber, F.H. \& Lee, J. (2015) Temperature-induced recruitment pulses of Arctic dwarf 
shrub communities. Journal of Ecology, 103, 489-501.

Callaghan, T.V., Crawford, R.M.M., Eronen, M., Hofgaard, A., Payette, S., Rees, W.G., Skre, O., Sveinbjörnsson, B., Vlassova, T.K. \& Werkman, B.R. (2002) The Dynamics of the Tundra-Taiga Boundary: An Overview and Suggested Coordinated and Integrated Approach to Research. Ambio, 3-5.

Chen, S., Zhang, Y., Wu, Q., Liu, S., Song, C., Xiao, J., Band, L.E. \& Vose, J.M. (2021) Vegetation structural change and $\mathrm{CO} 2$ fertilization more than offset gross primary production decline caused by reduced solar radiation in China. Agricultural and Forest Meteorology, 296.

Chen, T., Tang, G., Yuan, Y., Guo, H., Xu, Z., Jiang, G. \& Chen, X. (2020) Unraveling the relative impacts of climate change and human activities on grassland productivity in Central Asia over last three decades. Sci Total Environ, 743, 140649.

Comiso, J.C. \& Hall, D.K. (2014) Climate trends in the Arctic as observed from space. Wiley Interdiscip Rev Clim Change, 5, 389-409.

de Jong, R., Schaepman, M.E., Furrer, R., de Bruin, S. \& Verburg, P.H. (2013) Spatial relationship between climatologies and changes in global vegetation activity. Glob Chang Biol, 19, 19531964.

Deering, D.W., Eck, T.F. \& Banerjee, B. (1999) Characterization of the Reflectance Anisotropy of Three Boreal Forest Canopies in Spring-Summer. Remote Sensing of Environment, 67, 205-229.

Deng, C., Zhang, B., Cheng, L., Hu, L. \& Chen, F. (2019) Vegetation dynamics and their effects on surface water-energy balance over the Three-North Region of China. Agricultural and Forest Meteorology, 275, 79-90.

Devi, N., Hagedorn, F., Moiseev, P., Bugmann, H., Shiyatov, S., Mazepa, V. \& Rigling, A. (2008) 
Expanding forests and changing growth forms of Siberian larch at the Polar Urals treeline during the 20th century. Global Change Biology, 14, 1581-1591.

Ding, Y., Li, Z. \& Peng, S. (2020) Global analysis of time-lag and -accumulation effects of climate on vegetation growth. International Journal of Applied Earth Observation and Geoinformation, 92.

Douglas, T.A., Turetsky, M.R. \& Koven, C.D. (2020) Increased rainfall stimulates permafrost thaw across a variety of Interior Alaskan boreal ecosystems. npj Climate and Atmospheric Science, 3.

Ehbrecht, M., Seidel, D., Annighofer, P., Kreft, H., Kohler, M., Zemp, D.C., Puettmann, K., Nilus, R., Babweteera, F., Willim, K., Stiers, M., Soto, D., Boehmer, H.J., Fisichelli, N., Burnett, M., Juday, G., Stephens, S.L. \& Ammer, C. (2021) Global patterns and climatic controls of forest structural complexity. Nat Commun, 12, 519.

Elmendorf, S.C., Henry, G.H., Hollister, R.D., Bjork, R.G., Bjorkman, A.D., Callaghan, T.V., Collier, L.S., Cooper, E.J., Cornelissen, J.H., Day, T.A., Fosaa, A.M., Gould, W.A., Gretarsdottir, J., Harte, J., Hermanutz, L., Hik, D.S., Hofgaard, A., Jarrad, F., Jonsdottir, I.S., Keuper, F., Klanderud, K., Klein, J.A., Koh, S., Kudo, G., Lang, S.I., Loewen, V., May, J.L., Mercado, J., Michelsen, A., Molau, U., Myers-Smith, I.H., Oberbauer, S.F., Pieper, S., Post, E., Rixen, C., Robinson, C.H., Schmidt, N.M., Shaver, G.R., Stenstrom, A., Tolvanen, A., Totland, O., Troxler, T., Wahren, C.H., Webber, P.J., Welker, J.M. \& Wookey, P.A. (2012) Global assessment of experimental climate warming on tundra vegetation: heterogeneity over space and time. Ecol Lett, 15, 164-175.

Ettinger, A.K., Chamberlain, C.J., Morales-Castilla, I., Buonaiuto, D.M., Flynn, D.F.B., Savas, T., 
Samaha, J.A. \& Wolkovich, E.M. (2020) Winter temperatures predominate in spring phenological responses to warming. Nature Climate Change, 10, 1137-1142.

Feng, P., Guo, H., Chi, W., Chai, X., Sun, X., Xu, X., Ma, J., Rochaix, J.D., Leister, D., Wang, H., Lu, C. \& Zhang, L. (2016) Chloroplast retrograde signal regulates flowering. Proc Natl Acad Sci U S $A, 113,10708-10713$.

Forbes, B.C., Fauria, M.M. \& Zetterberg, P. (2010) Russian Arctic warming and 'greening' are closely tracked by tundra shrub willows. Global Change Biology, 16, 1542-1554.

Friedl, M.A., Sulla-Menashe, D., Tan, B., Schneider, A., Ramankutty, N., Sibley, A. \& Huang, X. (2010) MODIS Collection 5 global land cover: Algorithm refinements and characterization of new datasets. Remote Sensing of Environment, 114, 168-182.

Fyfe, J.C., Meehl, G.A., England, M.H., Mann, M.E., Santer, B.D., Flato, G.M., Hawkins, E., Gillett, N.P., Xie, S.-P., Kosaka, Y. \& Swart, N.C. (2016) Making sense of the early-2000s warming slowdown. Nature Climate Change, 6, 224-228.

Gamon, J.A., Huemmrich, K.F., Stone, R.S. \& Tweedie, C.E. (2013) Spatial and temporal variation in primary productivity (NDVI) of coastal Alaskan tundra: Decreased vegetation growth following earlier snowmelt. Remote Sensing of Environment, 129, 144-153.

Gan, G., Liu, Y. \& Sun, G. (2021) Understanding interactions among climate, water, and vegetation with the Budyko framework. Earth-Science Reviews, 212.

Garcia, R.A., Cabeza, M., Rahbek, C. \& Araujo, M.B. (2014) Multiple dimensions of climate change and their implications for biodiversity. Science, 344, 1247579.

Gonzalez-Suarez, P., Walker, C.H. \& Bennett, T. (2020) Bloom and bust: understanding the nature and regulation of the end of flowering. Curr Opin Plant Biol, 57, 24-30. 
Good, E.J., Ghent, D.J., Bulgin, C.E. \& Remedios, J.J. (2017) A spatiotemporal analysis of the relationship between near-surface air temperature and satellite land surface temperatures using 17 years of data from the ATSR series. Journal of Geophysical Research: Atmospheres, 122, 9185-9210.

Guanter, L., Frankenberg, C., Dudhia, A., Lewis, P.E., Gómez-Dans, J., Kuze, A., Suto, H. \& Grainger, R.G. (2012) Retrieval and global assessment of terrestrial chlorophyll fluorescence from GOSAT space measurements. Remote Sensing of Environment, 121, 236-251.

Guerschman, J.P., Hill, M.J., Leys, J. \& Heidenreich, S. (2020) Vegetation cover dependence on accumulated antecedent precipitation in Australia: Relationships with photosynthetic and nonphotosynthetic vegetation fractions. Remote Sensing of Environment, 240.

Harrison, S., Spasojevic, M.J. \& Li, D. (2020) Climate and plant community diversity in space and time. Proc Natl Acad Sci U S A, 117, 4464-4470.

He, X., He, K.S. \& Hyvönen, J. (2016) Will bryophytes survive in a warming world? Perspectives in Plant Ecology, Evolution and Systematics, 19, 49-60.

Hedemann, C., Mauritsen, T., Jungclaus, J. \& Marotzke, J. (2017) The subtle origins of surface-warming hiatuses. Nature Climate Change, 7, 336-339.

Holtmeier, F.-K. \& Broll, G. (2019) Treeline Research-From the Roots of the Past to Present Time. A Review. Forests, 11.

Hu, Y., Jiang, L., Wang, S., Zhang, Z., Luo, C., Bao, X., Niu, H., Xu, G., Duan, J., Zhu, X., Cui, S. \& Du, M. (2016) The temperature sensitivity of ecosystem respiration to climate change in an alpine meadow on the Tibet plateau: A reciprocal translocation experiment. Agricultural and Forest Meteorology, 216, 93-104. 
Huete, A., Didan, K., Miura, T., Rodriguez, E.P., Gao, X. \& Ferreira, L.G. (2002) Overview of the radiometric and biophysical performance of the MODIS vegetation indices. Remote Sensing of Environment, 83, 195-213.

Kogan, F.N. (1995a) Application of vegetation index and brightness temperature for drought detection. Advances in Space Research, 15, 91-100.

Kogan, F.N. (1995b) Droughts of the Late 1980s in the United States as Derived from NOAA PolarOrbiting Satellite Data. Bulletin of the American Meteorological Society, 76, 655-668.

Kong, D., Miao, C., Wu, J., Zheng, H. \& Wu, S. (2020) Time lag of vegetation growth on the Loess Plateau in response to climate factors: Estimation, distribution, and influence. Sci Total Environ, 744, 140726.

Kutzbach, L., Wille, C. \& Pfeiffer, E.M. (2007) The exchange of carbon dioxide between wet arctic tundra and the atmosphere at the Lena River Delta, Northern Siberia. Biogeosciences, 4.

Law, B.E., Falge, E., Gu, L., Baldocchi, D.D., Bakwin, P., Berbigier, P., Davis, K., Dolman, A.J., Falk, M., Fuentes, J.D., Goldstein, A., Granier, A., Grelle, A., Hollinger, D., Janssens, I.A., Jarvis, P., Jensen, N.O., Katul, G., Mahli, Y., Matteucci, G., Meyers, T., Monson, R., Munger, W., Oechel, W., Olson, R., Pilegaard, K., Paw U, K.T., Thorgeirsson, H., Valentini, R., Verma, S., Vesala, T., Wilson, K. \& Wofsy, S. (2002) Environmental controls over carbon dioxide and water vapor exchange of terrestrial vegetation. Agricultural and Forest Meteorology, 113, 97-120.

Li, X. \& Xiao, J. (2020) Global climatic controls on interannual variability of ecosystem productivity: Similarities and differences inferred from solar-induced chlorophyll fluorescence and enhanced vegetation index. Agricultural and Forest Meteorology, 288-289.

Loranty, M.M., Lieberman-Cribbin, W., Berner, L.T., Natali, S.M., Goetz, S.J., Alexander, H.D. \& 
Kholodov, A.L. (2016) Spatial variation in vegetation productivity trends, fire disturbance, and soil carbon across arctic-boreal permafrost ecosystems. Environmental Research Letters, 11.

Mack, M.C., Bret-Harte, M.S., Hollingsworth, T.N., Jandt, R.R., Schuur, E.A., Shaver, G.R. \& Verbyla, D.L. (2011) Carbon loss from an unprecedented Arctic tundra wildfire. Nature, 475, 489-492.

McMahon, S., Harrison, S., Armbruster, W., Bartlein, P., Beale, C., Edwards, M., Kattge, J., Midgley, G., Morin, X. \& Prentice, I. (2011) Improving assessment and modelling of climate change impacts on global terrestrial biodiversity. Trends in ecology \& evolution, 26, 249-259.

Miles, M.W., Miles, V.V. \& Esau, I. (2019) Varying climate response across the tundra, forest-tundra and boreal forest biomes in northern West Siberia. Environmental Research Letters, 14.

Miles, V.V. \& Esau, I. (2016) Spatial heterogeneity of greening and browning between and within bioclimatic zones in northern West Siberia. Environmental Research Letters, 11.

Montesano, P., Neigh, C., Sexton, J., Feng, M., Channan, S., Ranson, K. \& Townshend, J. (2016) Calibration and Validation of Landsat Tree Cover in the Taiga-Tundra Ecotone. Remote Sensing, 8.

Mulder, C.P., Iles, D.T. \& Rockwell, R.F. (2017) Increased variance in temperature and lag effects alter phenological responses to rapid warming in a subarctic plant community. Glob Chang Biol, 23, $801-814$

Myers-Smith, I.H., Elmendorf, S.C., Beck, P.S.A., Wilmking, M., Hallinger, M., Blok, D., Tape, K.D., Rayback, S.A., Macias-Fauria, M., Forbes, B.C., Speed, J.D.M., Boulanger-Lapointe, N., Rixen, C., Lévesque, E., Schmidt, N.M., Baittinger, C., Trant, A.J., Hermanutz, L., Collier, L.S., Dawes, M.A., Lantz, T.C., Weijers, S., Jørgensen, R.H., Buchwal, A., Buras, A., Naito, A.T., Ravolainen, V., Schaepman-Strub, G., Wheeler, J.A., Wipf, S., Guay, K.C., Hik, D.S. \& Vellend, M. (2015) 
Climate sensitivity of shrub growth across the tundra biome. Nature Climate Change, 5, 887891.

Myers-Smith, I.H., Kerby, J.T., Phoenix, G.K., Bjerke, J.W., Epstein, H.E., Assmann, J.J., John, C., Andreu-Hayles, L., Angers-Blondin, S., Beck, P.S.A., Berner, L.T., Bhatt, U.S., Bjorkman, A.D., Blok, D., Bryn, A., Christiansen, C.T., Cornelissen, J.H.C., Cunliffe, A.M., Elmendorf, S.C., Forbes, B.C., Goetz, S.J., Hollister, R.D., de Jong, R., Loranty, M.M., Macias-Fauria, M., Maseyk, K., Normand, S., Olofsson, J., Parker, T.C., Parmentier, F.-J.W., Post, E., SchaepmanStrub, G., Stordal, F., Sullivan, P.F., Thomas, H.J.D., Tømmervik, H., Treharne, R., Tweedie, C.E., Walker, D.A., Wilmking, M. \& Wipf, S. (2020) Complexity revealed in the greening of the Arctic. Nature Climate Change, 10, 106-117.

Nemani, R.R., Keeling, C.D., Hashimoto, H., Jolly, W.M., Piper, S.C., Tucker, C.J., Myneni, R.B. \& Running, S.W. (2003) Climate-driven increases in global terrestrial net primary production from 1982 to 1999. Science, 300, 1560-1563.

Park, T., Ganguly, S., Tømmervik, H., Euskirchen, E.S., Høgda, K.-A., Karlsen, S.R., Brovkin, V., Nemani, R.R. \& Myneni, R.B. (2016) Changes in growing season duration and productivity of northern vegetation inferred from long-term remote sensing data. Environmental Research Letters, 11.

Pearson, R.G., Phillips, S.J., Loranty, M.M., Beck, P.S.A., Damoulas, T., Knight, S.J. \& Goetz, S.J. (2013) Shifts in Arctic vegetation and associated feedbacks under climate change. Nature Climate Change, 3, 673-677.

Pecl, G.T., Araujo, M.B., Bell, J.D., Blanchard, J., Bonebrake, T.C., Chen, I.C., Clark, T.D., Colwell, R.K., Danielsen, F., Evengard, B., Falconi, L., Ferrier, S., Frusher, S., Garcia, R.A., Griffis, R.B., 
Hobday, A.J., Janion-Scheepers, C., Jarzyna, M.A., Jennings, S., Lenoir, J., Linnetved, H.I., Martin, V.Y., McCormack, P.C., McDonald, J., Mitchell, N.J., Mustonen, T., Pandolfi, J.M., Pettorelli, N., Popova, E., Robinson, S.A., Scheffers, B.R., Shaw, J.D., Sorte, C.J., Strugnell, J.M., Sunday, J.M., Tuanmu, M.N., Verges, A., Villanueva, C., Wernberg, T., Wapstra, E. \& Williams, S.E. (2017) Biodiversity redistribution under climate change: Impacts on ecosystems and human well-being. Science, 355.

Penuelas, J. \& Filella, I. (2001) Responses to a Warming World. Science (New York, N.Y.), 294, 793-795.

Phoenix, G.K. \& Bjerke, J.W. (2016) Arctic browning: extreme events and trends reversing arctic greening. Glob Chang Biol, 22, 2960-2962.

Piao, S., Liu, Q., Chen, A., Janssens, I.A., Fu, Y., Dai, J., Liu, L., Lian, X., Shen, M. \& Zhu, X. (2019) Plant phenology and global climate change: Current progresses and challenges. Global Change Biology, 25, 1922-1940.

Piao, S., Tan, J., Chen, A., Fu, Y.H., Ciais, P., Liu, Q., Janssens, I.A., Vicca, S., Zeng, Z., Jeong, S.J., Li, Y., Myneni, R.B., Peng, S., Shen, M. \& Penuelas, J. (2015) Leaf onset in the northern hemisphere triggered by daytime temperature. Nat Commun, 6, 6911.

Qin, D. (2004) CLIMATE CHANGE SCIENCES INTO THE 21st CENTURY: FACTS, IMPACT AND STRATEGIES ADDRESSING CLIMATE CHANGE. Science \& Technology Review, 22, 4-7.

Reich, P.B., Sendall, K.M., Stefanski, A., Rich, R.L., Hobbie, S.E. \& Montgomery, R.A. (2018) Effects of climate warming on photosynthesis in boreal tree species depend on soil moisture. Nature, 562, 263-267.

Robinson, S.A., King, D.H., Bramley-Alves, J., Waterman, M.J., Ashcroft, M.B., Wasley, J., Turnbull, J.D., Miller, R.E., Ryan-Colton, E., Benny, T., Mullany, K., Clarke, L.J., Barry, L.A. \& Hua, Q. 
(2018) Rapid change in East Antarctic terrestrial vegetation in response to regional drying. Nature Climate Change, 8, 879-884.

Sandholt, I., Rasmussen, K. \& Andersen, J. (2002) A simple interpretation of the surface temperature/vegetation index space for assessment of surface moisture status. Remote Sensing of Environment, 79, 213-224.

Seddon, A.W., Macias-Fauria, M., Long, P.R., Benz, D. \& Willis, K.J. (2016) Sensitivity of global terrestrial ecosystems to climate variability. Nature, 531, 229-232.

Vicente-Serrano, S.M., Gouveia, C., Camarero, J.J., Begueria, S., Trigo, R., Lopez-Moreno, J.I., AzorinMolina, C., Pasho, E., Lorenzo-Lacruz, J., Revuelto, J., Moran-Tejeda, E. \& Sanchez-Lorenzo, A. (2013) Response of vegetation to drought time-scales across global land biomes. Proc Natl Acad Sci U S A, 110, 52-57.

Walsh, J.E., Ballinger, T.J., Euskirchen, E.S., Hanna, E., Mård, J., Overland, J.E., Tangen, H. \& Vihma, T. (2020) Extreme weather and climate events in northern areas: A review. Earth-Science Reviews, 209.

Walther, C., Hüttich, C., Urban, M. \& Schmullius, C. (2019) Modelling the Arctic taiga-tundra ecotone using ALOS PALSAR and optical earth observation data. International Journal of Applied Earth Observation and Geoinformation, 81, 195-206.

Wan, Z. (2008) New refinements and validation of the MODIS Land-Surface Temperature/Emissivity products. Remote Sensing of Environment, 112, 59-74.

Weedon, G.P., Balsamo, G., Bellouin, N., Gomes, S., Best, M.J. \& Viterbo, P. (2018) The WFDEI Meteorological Forcing Data. Research Data Archive at the National Center for Atmospheric Research, Computational and Information Systems Laboratory, Boulder, CO. 
Wen, Y., Liu, X., Xin, Q., Wu, J., Xu, X., Pei, F., Li, X., Du, G., Cai, Y., Lin, K., Yang, J. \& Wang, Y. (2019) Cumulative Effects of Climatic Factors on Terrestrial Vegetation Growth. Journal of Geophysical Research: Biogeosciences, 124, 789-806.

Willis, K., Jeffers, E. \& Tovar Ingar, C. (2018) What makes a terrestrial ecosystem resilient? Science, 359, 988-989.

Wu, D., Zhao, X., Liang, S., Zhou, T., Huang, K., Tang, B. \& Zhao, W. (2015) Time-lag effects of global vegetation responses to climate change. Glob Chang Biol, 21, 3520-3531.

Xu, L., Myneni, R.B., Chapin Iii, F.S., Callaghan, T.V., Pinzon, J.E., Tucker, C.J., Zhu, Z., Bi, J., Ciais, P., Tømmervik, H., Euskirchen, E.S., Forbes, B.C., Piao, S.L., Anderson, B.T., Ganguly, S., Nemani, R.R., Goetz, S.J., Beck, P.S.A., Bunn, A.G., Cao, C. \& Stroeve, J.C. (2013) Temperature and vegetation seasonality diminishment over northern lands. Nature Climate Change, 3, 581-586.

Yıldırım, H.B., Teke, A. \& Antonanzas-Torres, F. (2018) Evaluation of classical parametric models for estimating solar radiation in the Eastern Mediterranean region of Turkey. Renewable and Sustainable Energy Reviews, 82, 2053-2065.

Yuan, W., Zheng, Y., Piao, S., Ciais, P., Lombardozzi, D., Wang, Y., Ryu, Y., Chen, G., Dong, W., Hu, Z., Jain, A., Jiang, C., Kato, E., Li, S., Lienert, S., Liu, S., Nabel, J., Qin, Z., Quine, T. \& Yang, S. (2019) Increased atmospheric vapor pressure deficit reduces global vegetation growth. Science Advances, 5, eaax1396.

Zeng, F.-W., Collatz, G., Pinzon, J. \& Ivanoff, A. (2013) Evaluating and Quantifying the Climate-Driven Interannual Variability in Global Inventory Modeling and Mapping Studies (GIMMS) Normalized Difference Vegetation Index (NDVI3g) at Global Scales. Remote Sensing, 5, 3918- 
3950.

Zhu, Z., Piao, S., Myneni, R.B., Huang, M., Zeng, Z., Canadell, J.G., Ciais, P., Sitch, S., Friedlingstein, P., Arneth, A., Cao, C., Cheng, L., Kato, E., Koven, C., Li, Y., Lian, X., Liu, Y., Liu, R., Mao, J., Pan, Y., Peng, S., Peñuelas, J., Poulter, B., Pugh, T.A.M., Stocker, B.D., Viovy, N., Wang, X., Wang, Y., Xiao, Z., Yang, H., Zaehle, S. \& Zeng, N. (2016) Greening of the Earth and its drivers. Nature Climate Change, 6, 791-795.

\section{Declarations :}

- Ethics approval and consent to participate

Not applicable

- Consent for publication

Not applicable

- Availability of data and material

All datasets analysed during the current study have listed in Table 1. The datasets generated during the current study are available from the corresponding author on reasonable request.

Table 1 Summary of the datasets

\begin{tabular}{cc}
\hline Dataset and source & Notes \\
\hline Enhanced Vegetation Index & The images are generated every month at $0.05^{\circ}$ spatial \\
(https://pdaac.usgs.gov/products/mod13c2v006/) & resolution during 2000 -present \\
Land Surface Temperature & The images are generated every month at $0.05^{\circ}$ spatial \\
(https://pdaac.usgs.gov/products/mod11c3v006/) & resolution during 2000 -present \\
Precipitation & The images are generated every month at $0.1^{\circ}$ spatial \\
(https://disc.gsfc.nasa.gov/datasets/GPM_3IMERGM_06) & resolution during $2000-$ present \\
Solar Radiation (https://rda.ucar.edu/) & The images are generated every 8 hours at $0.5^{\circ}$ spatial
\end{tabular}


resolution during 2000-2016

Land Cover

(https://lpdaac.usgs.gov/products/mcd12c1v006/)
The images are generated annually at $0.05^{\circ}$ spatial

resolution during 2001-present

- Competing interests

The authors declare that they have no competing interests.

- $\quad$ Funding

This research was supported by grants from the National Natural Science

Foundation of China (Grants 42061134017, 41877165, 42071042).

- Authors' contributions

Shangyu Shi: acquisition, analysis, drafted the work

Ping Wang: design of the work, substantively revised, funding acquisition.

Jingjie Yu: design of the work, substantively revised, funding acquisition.

Yichi Zhang: substantively revised, validation.

- Acknowledgements

Not applicable 

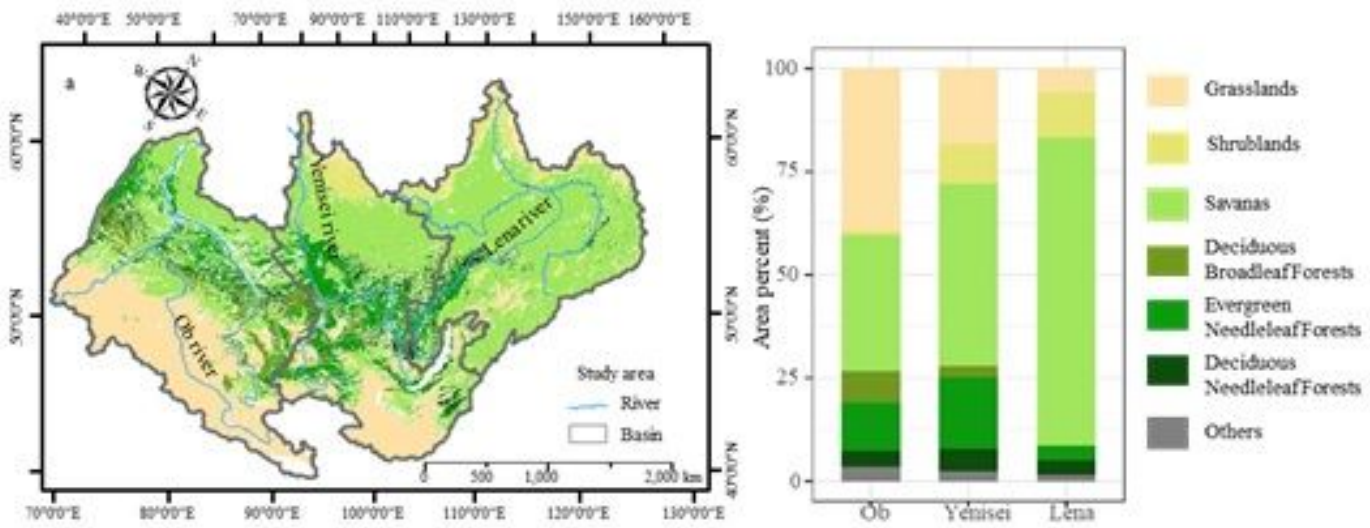

\section{Figure 1}

Spatial distribution of stable land cover of Siberia during 2001-2016 (a), the area percent occupied by each land cover in different basins (b). Note: The designations employed and the presentation of the material on this map do not imply the expression of any opinion whatsoever on the part of Research Square concerning the legal status of any country, territory, city or area or of its authorities, or concerning the delimitation of its frontiers or boundaries. This map has been provided by the authors.
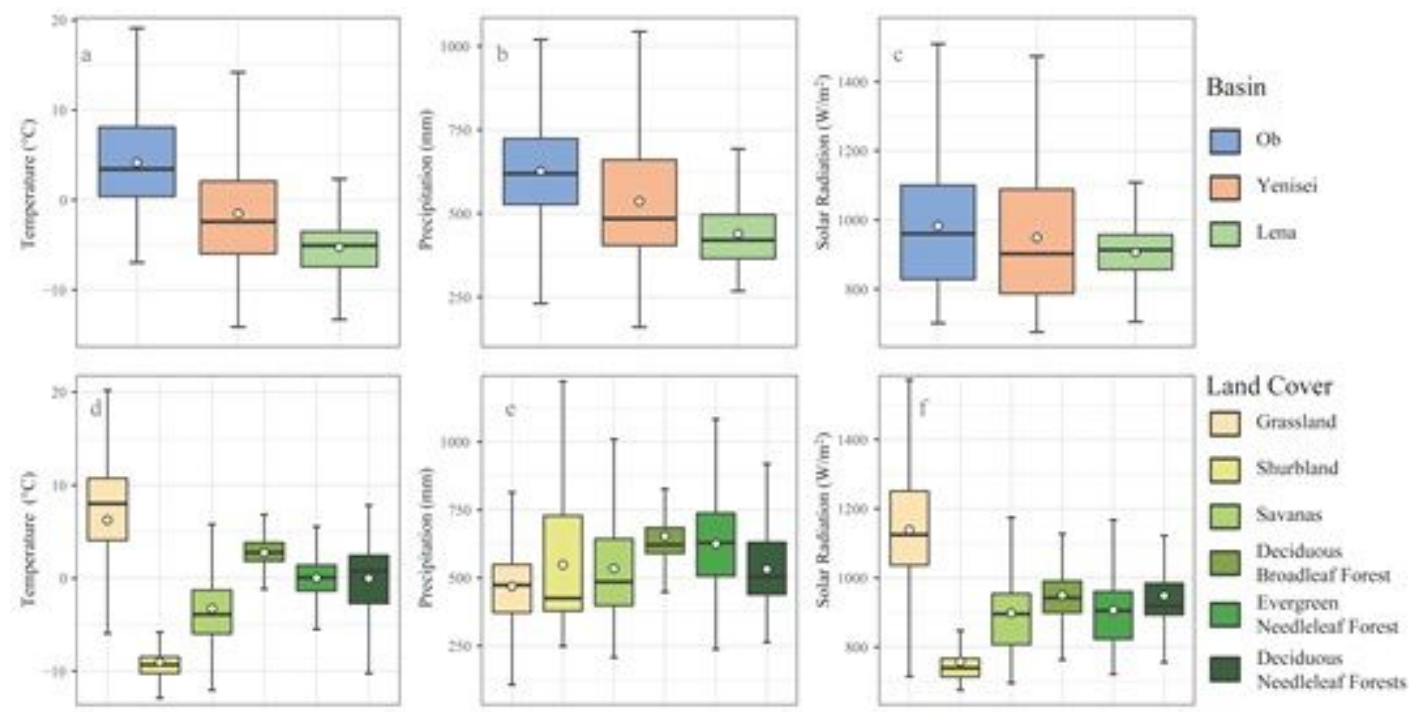

Figure 2

The difference in climate factors among each basin and land cover category Note: the upper and lower bounds of the whiskers indicate the maximum and minimum, respectively; the lower, middle and upper bounds of the box indicate the 1st, 2nd and 3rd quartiles, respectively; the dot in each box indicates the mean. 


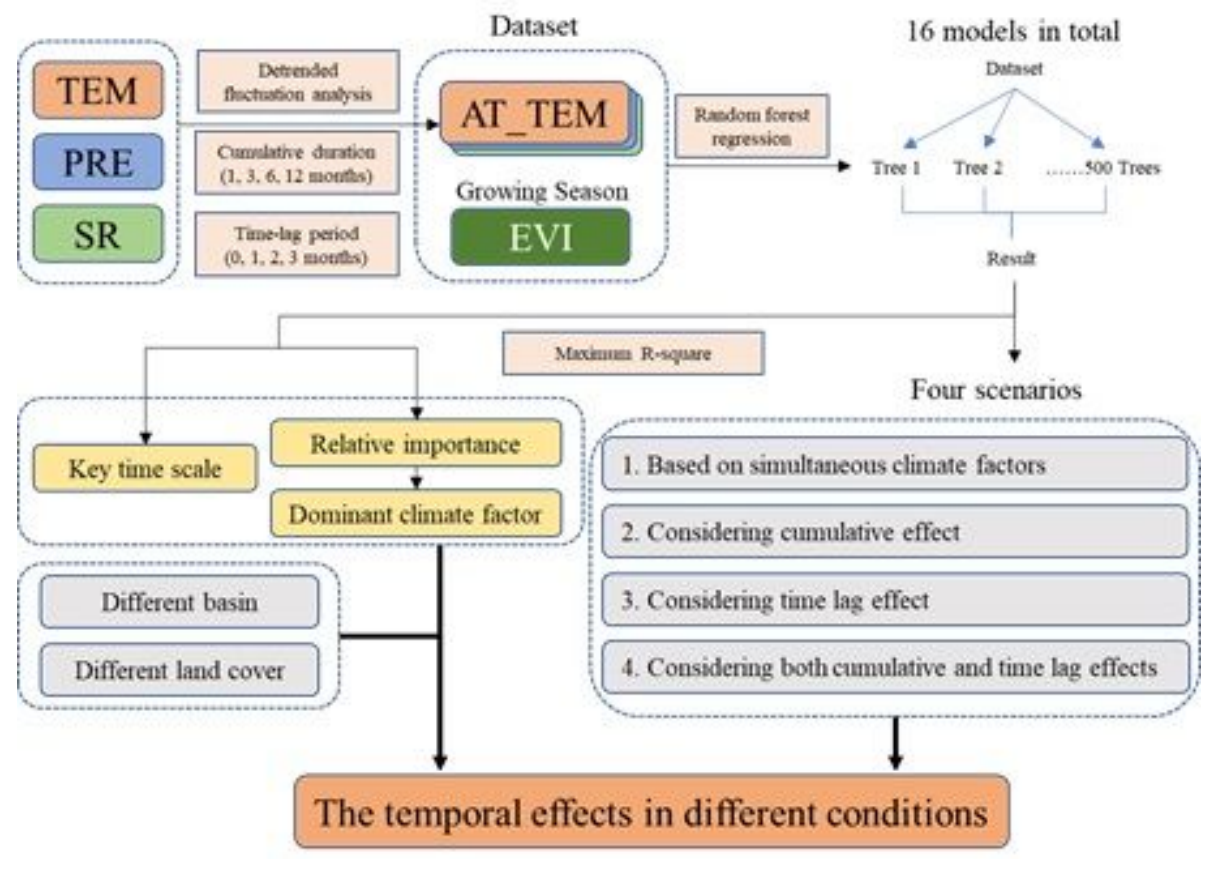

\section{Figure 3}

Flow chart of the algorithm used to analyse the temporal effects.
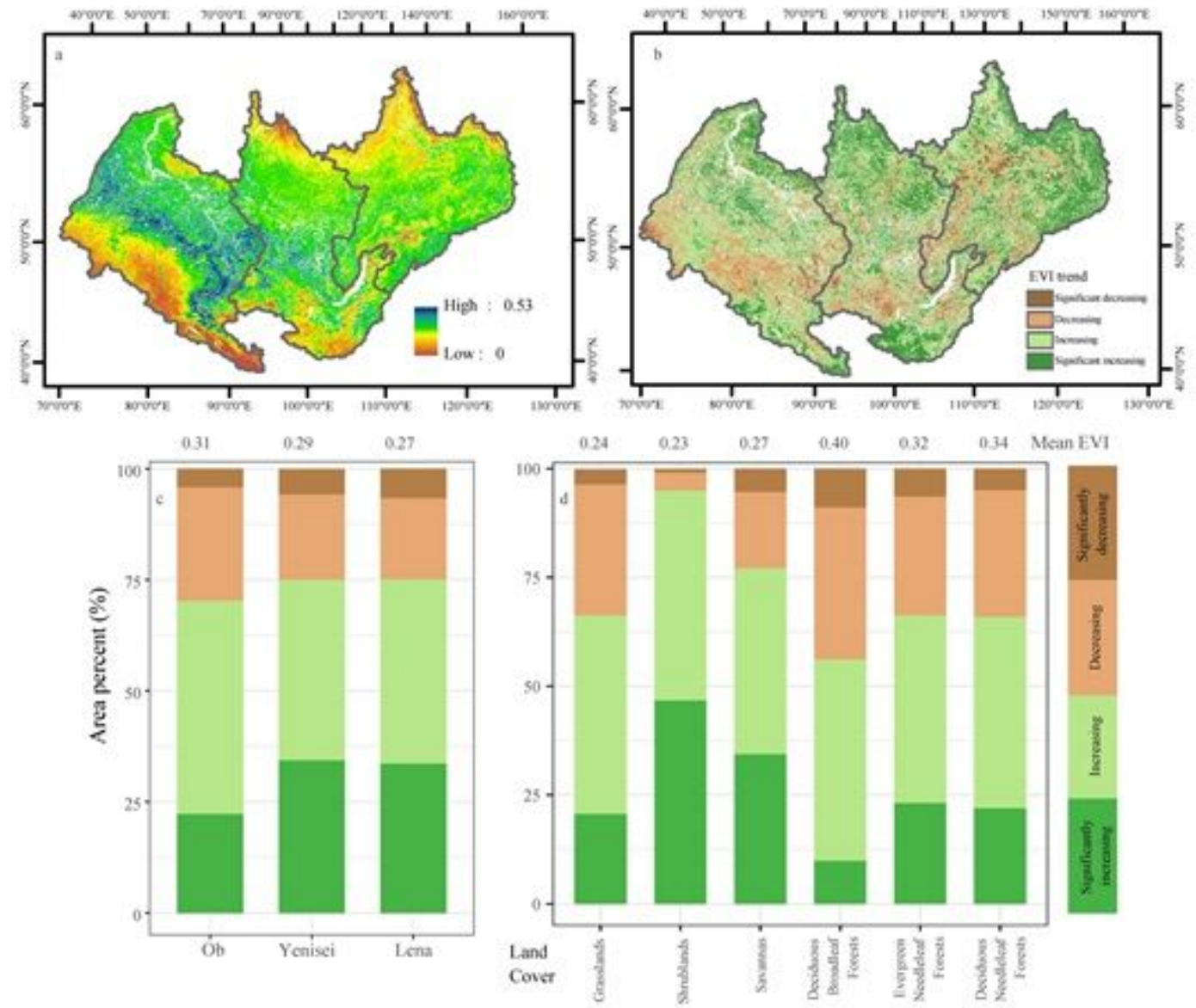

Figure 4 
Spatial distribution of the mean growing season EVI (a) and the trend (b) during 2000-2016. The area percent of different range EVI trends in each basin (c) and land cover category (d). Note: the mean EVI is provided above each bar. Note: The designations employed and the presentation of the material on this map do not imply the expression of any opinion whatsoever on the part of Research Square concerning the legal status of any country, territory, city or area or of its authorities, or concerning the delimitation of its frontiers or boundaries. This map has been provided by the authors.

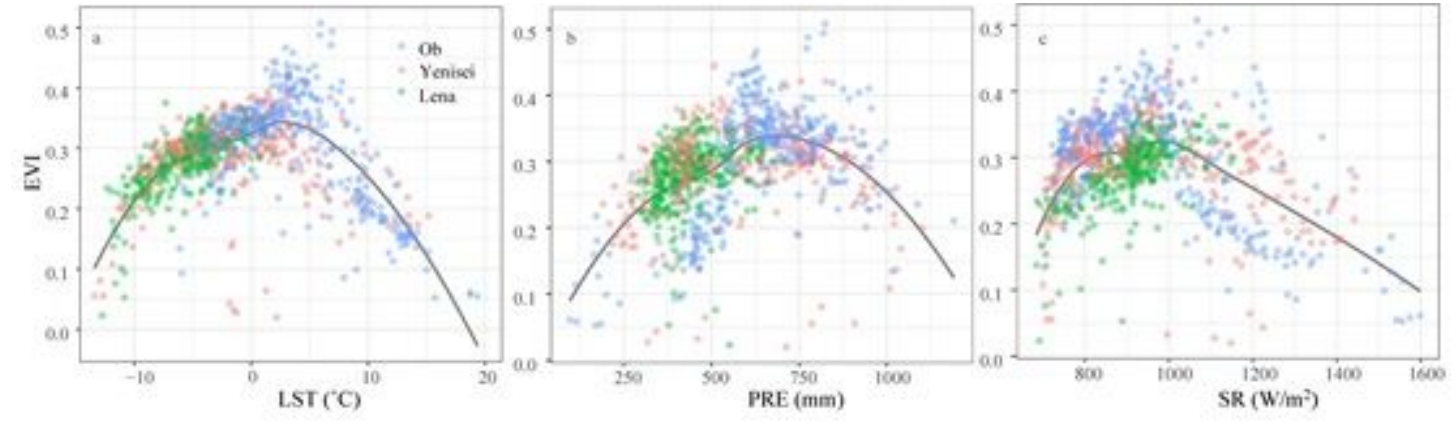

\section{Figure 5}

The relationship between the EVI and LST (a), PRE (b) and SR (c) across Siberia. 

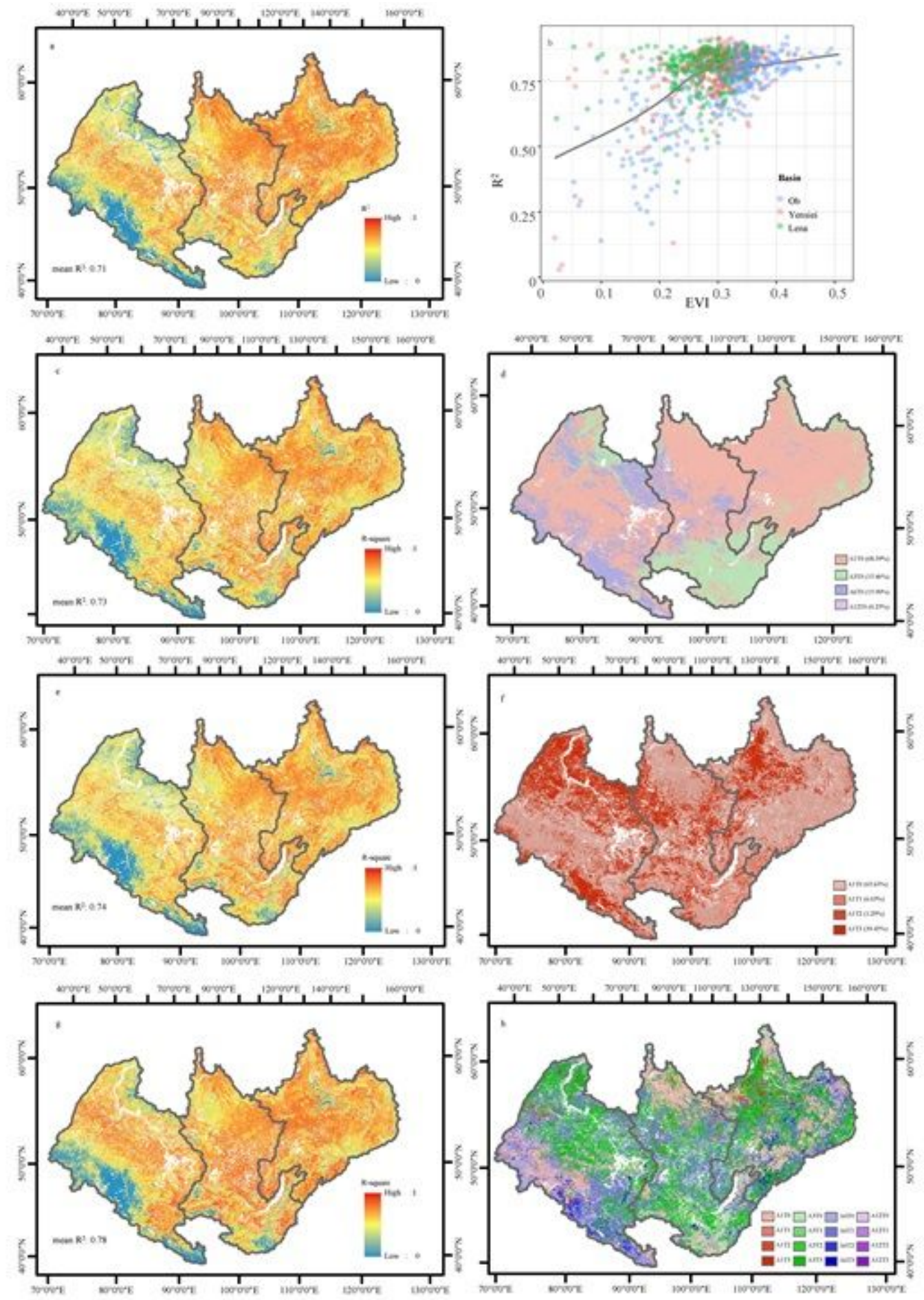

Figure 6

Spatial distribution of the R2 of random forest regression under four scenarios (a, c, e, g) and the corresponding time scale of cumulative duration and time-lag period $(d, f, h)$. The relationship between the EVI and R2 (b). Note: A1T0 in figure b means cumulative duration is one month and the time-lag period is zero months, same as the rest. Note: The designations employed and the presentation of the material on this map do not imply the expression of any opinion whatsoever on the part of Research Square concerning the legal status of any country, territory, city or area or of its authorities, or concerning the delimitation of its frontiers or boundaries. This map has been provided by the authors. 

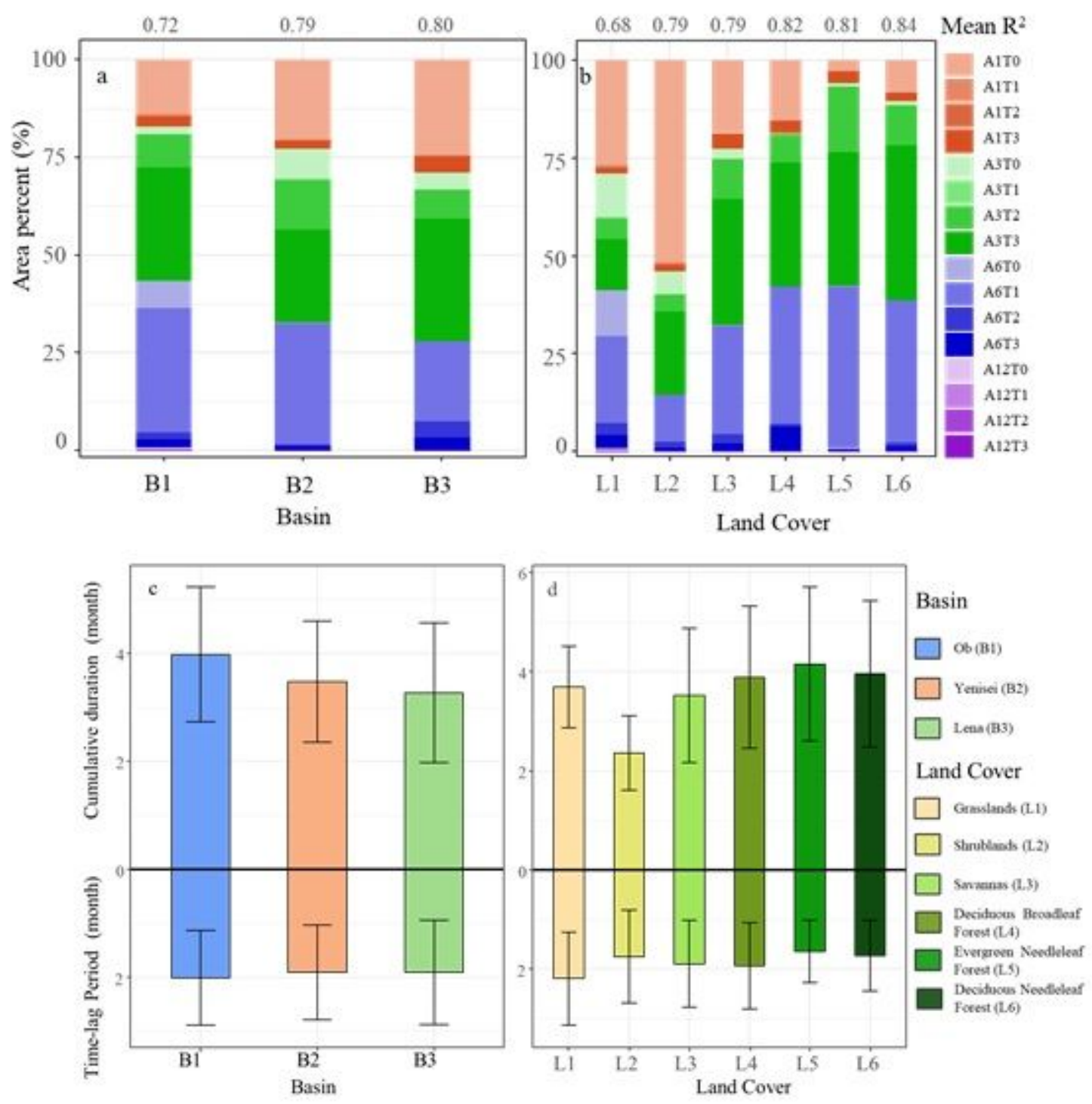

Figure 7

The area percent occupied by each time scale $(a, b)$, the cumulative duration (upper of $c, d$ ) and the timelag period (lower of $c, d)$ of each basin $(a, c)$ and land cover category $(b, d)$. Note: the bounds of the boxes in $\mathrm{c}-\mathrm{f}$ indicate the mean and mean \pm standard deviation. 

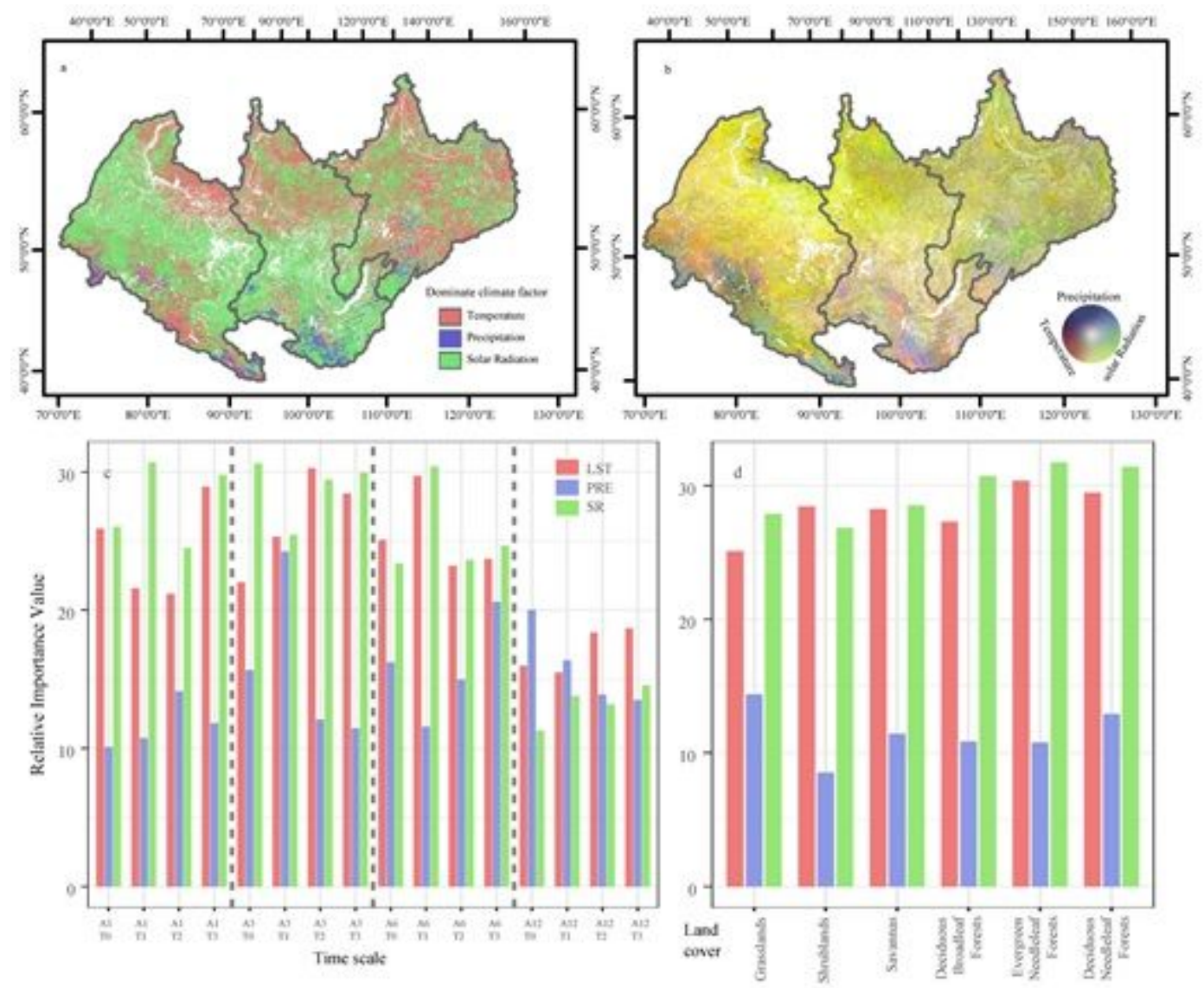

Figure 8

Spatial distribution of the dominant climate factor of the EVI (a) and RGB composite map of the relative importance of climate factors (b). The relative importance of climate factors at different time scales (c) and among land cover categories (d). Note: LST, PRE and SR are labelled red, blue and green, respectively. Moreover, the relative importance values of LST, PRE and SR were linearly transformed to the range of 0 255 to complete the map. Note: The designations employed and the presentation of the material on this map do not imply the expression of any opinion whatsoever on the part of Research Square concerning the legal status of any country, territory, city or area or of its authorities, or concerning the delimitation of its frontiers or boundaries. This map has been provided by the authors. 

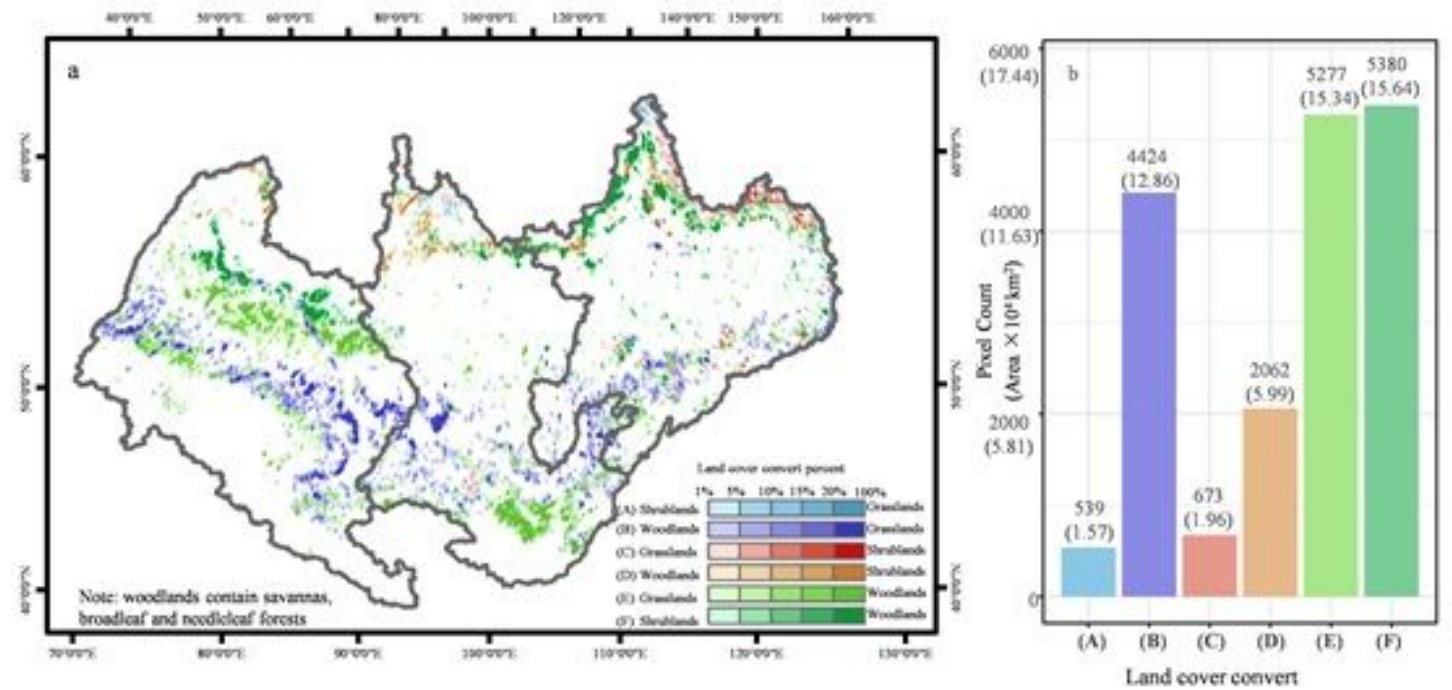

Figure 9

Land cover conversion in Siberia during 2001-2016. Note: The designations employed and the presentation of the material on this map do not imply the expression of any opinion whatsoever on the part of Research Square concerning the legal status of any country, territory, city or area or of its authorities, or concerning the delimitation of its frontiers or boundaries. This map has been provided by the authors. 